\title{
IMPACT OF AIRLINE BUSINESS MODELS, MARKET SEGMENTS AND \\ GEOGRAPHICAL REGIONS ON AIRCRAFT CABIN CONFIGURATIONS
}

\author{
Oluwaferanmi Oguntona (corresponding author) \\ in-motion GmbH, Munich, Germany
}

Kay O. Ploetner, Marcia Urban, Raoul Rothfeld, and Mirko Hornung

Bauhaus Luftfahrt e.V., Taufkirchen, Germany

\begin{abstract}
Besides the significance of estimating aircraft seat capacity for airline operating cost and yield estimation as well as for the conceptual design of aircraft, airline fleet planning requires an understanding of aircraft cabin configuration. This paper presents the impact of airline business models, market segments in terms of flight distances, and geographical regions on aircraft cabin configuration, i.e. aircraft seat capacities and installed seats per cabin class. Using the historical databases of global low-cost carriers and airline flight schedules between 2000 and 2016, two ABM clusters - full-service network carriers (FSNCs) and low-cost carriers (LCCS) - were developed, while using seven already-developed passenger-aircraft clusters. Focusing on the jet commuter (JC), narrow-body (NB) and long-range (LR) aircraft clusters, studies were conducted on the historical development of aircraft cluster seat capacities at different abstraction levels: global, airline business model, intra- and inter-regional flight distances, as well as a combination of ABM and (inter)regional flights. Selected results were further analysed using statistical tests on the mean and regression analysis. The analysis results show that LCCs use aircraft that have less average scheduled and less average maximum possible seats than FSNCs. Specifically, FSNCs use significantly bigger aircraft types in LR cluster than LCCs, while LCCs use significantly bigger aircraft types in JC cluster than FSNCs. Furthermore, average cabin utilisation of aircraft clusters scheduled by LCCs are significantly higher than average cabin utilisation scheduled by FSNCs. With increasing distance, average cabin utilisation also significantly reduces.
\end{abstract}

\section{KEYWORDS}

Aircraft seat capacity, airline business model, aircraft cabin utilisation

Oluwaferanmi Oguntona: Project Staff, Flash Analyst, Automotive Email: oluwaferanmi.oguntona@in-motion.de

Dr. Kay O. Ploetner: Head, Economics and Transportation

Email: kay.ploetner@bauhaus-luftfahrt.net

Marcia Urban: Research Associate, Economics and Transportation

Email: marcia.urban@bauhaus-luftfahrt.net

Raoul Rothfeld: Research Associate, Economics and Transportation

Email: raoul.rothfeld@bauhaus-luftfahrt.net

Prof. Dr.-Ing. Mirko Hornung: Executive Director, Research and Technology

Email: mirko.hornung@bauhaus-luftfahrt.net 


\section{MOTIVATION}

Over the past few decades, novel airline business models (ABMs) have been introduced to the air transport market in addition to that of the traditional full-service network carriers. One example is the low-cost business model on short-to-medium haul markets introduced by Southwest Airlines in 1971 in the US and later adopted in 1991 by Ryanair within Europe. In addition, long-haul low-cost carriers such as AirAsia X, Jetstar Airways and Norwegian Air Shuttle have recently increased their market share (Leigh Fisher, 2015), although similar services were offered mainly on the transatlantic routes by Icelandic Airlines in the 1960s and 1970s and then by Laker Airways. Other than business models targeting price-sensitive markets through cost leadership and the full-service network carrier business model, airline variations and specialisations currently exist.

A cluster analysis of selected low-cost and full-service network carriers resulted in seven clusters which further subdivide the two established ABMs: a point-to-point low-cost carrier, a hub-and-spoke low-cost carrier, a global hybrid carrier, a medium size network carrier, a global niche market network carrier, a high-quality network carrier and a large size network carrier (Klemm, 2015). Other studies have applied the cluster analysis methodology to specific markets (Heinz \& O'Connell, 2013). For example, (Heinz and O'Connell, 2013) named the following airline clusters: full-service network carriers, established regional carriers, long-haul niche carriers, true low-cost carriers, emerging regional/low-cost carriers, emerging fullservice network carriers, and small full-service carriers. It can be concluded that the two established ABMs, the low-cost carrier (LCC) and the full-service network carrier (FSNC), constitute a foundation on which more specific business model variations can be based. The former charter carrier business model has shifted towards the low-cost model (Bieger \& Wittmer, 2006) which is why earlier studies considered it to a certain extent by analysing the low-cost carrier business model.

Nevertheless, irrespective of the business model chosen by an airline, the common unit of airline capacity is the available seat kilometre (ASK) or the available seat mile (ASM) and the available tonne kilometre (ATK) or the available tonne mile (ATM). Therefore, an evaluation of how aircraft cabins are configured is significant for many aspects of the aviation system, including airline operating cost and yield estimation, aircraft conceptual design and airline fleet planning. 


\subsection{Motivation for Airline Operating Cost and Yield Estimation}

The offered products by an airline can be categorised into ground and on-board services, the latter mainly depending on the aircraft cabin with its installed cabin classes, offered seat configurations and other services such as infotainment, food and beverages. The main cabin classes were traditionally first class (F), business class (C) and economy class (Y), however, premium economy class (PY) has increasingly gained attention amongst both LCCs and FSNCs. The number of cabin classes, seats per cabin class and total installed seats offered by each $A B M$ are essential for operating cost and yield estimations.

\subsection{Motivation for Aircraft Conceptual Design}

In the aircraft conceptual design phase, one of the first aircraft design parameters that needs to be fixed, is the design payload at the design range (Raymer, 1992). For a later refinement during the preliminary aircraft design phase, the number of cabin classes and number of installed seats per cabin class are essential information required for defining the fuselage cross-section and the overall length. Therefore, additional cabin information about design seat widths, seat pitches and additional cabin monuments (Nita \& Scholz, 2010) is necessary. These vary with airline business models as well as for regional, short-haul and long-haul operations.

\subsection{Motivation for Future Fleet Planning}

To determine the future fleet needs of an airline, fleet planners consider the occupancy level (seat and freight load factors) as well as the level of competition on the markets they serve. Thus, with increasing competition in a certain market and airport capacity constraints, an airline would choose to increase the installed seats on its aircraft to retain its market share or claim a higher market share (Berster, Gelhausen, \& Wilken, 2015). This will also occur when checking the break-even load factor of the planned aircraft (Clark, 2007).

Furthermore, a proper description of the installed seats and cargo weights of the modelled aircraft types is necessary for longer-term fleet planning and the evaluation of global emissions by airlines (IPCC, 1999). Therefore, this study evaluates the factors affecting aircraft cabin configuration (mainly installed seats, but also seats per cabin class as well as the level of cabin utilisation) and the impact of these factors by the use of empirical data.

\section{REVIEW OF EXISTING STUDIES}

The most common passenger metrics, fuel burn per seat-kilometre and range, used in aircraft performance evaluation are dependent on the aircraft payload configuration, i.e. the seat to cargo weight ratios (IPCC, 1999). According to IPCC (1999), this configuration varies among airlines and is dependent on market considerations. 
Kownatzki (2011) also identified airline business models as a main reason for differences in the number of installed seats and configurations of the same aircraft type. Other factors identified as affecting the number of seats and seat class mix are geographic considerations, competition level, flight timing, and target customers. Airlines thus adopt both high and lowend options, depending on the market segment, flight timing and the target customers.

Airline business models differ in several characteristics. One of the most significant characteristics is the number of installed seats since it affects the unit costs for an airline (Doganis, 2002). The seat density in the fleets of low-cost carriers (LCCs) is about $15-20 \%$ higher (Stimac, Vince, \& Vidovic, 2012) giving them an operational advantage compared with full-service network carriers (FSNCs) (Vidović, Štimac, \& Vince, 2013). Miyoshi and Mason (2009) confirmed this in their analysis on the carbon emissions of different airlines and aircraft types. For the European short-haul market, they identified significant differences in the carbon emissions per passenger kilometre between FSNCs and LCCs and concluded that the latter achieved lower carbon emissions due to an operation of new aircraft types, exceedingly high load factors, and a high seat density (Miyoshi \& Mason, 2009).

Besides the lower carbon emissions per passenger kilometre, a higher seat density provides a cost advantage for the operating airline (Gillen \& Gados, 2008). Thus, airlines with a costleadership strategy, i.e. LCCs, addressing a price-sensitive target group of passengers operate their aircraft with more seats compared to airlines with other business models.

Market size as well as route distance have a positive effect on the size of an aircraft operated by the airline, which leads to the conclusion that the number of seats increases with an increase in the route distance (Givoni \& Rietveld, 2009). Pai (2010) also identified a positive correlation between route distance and aircraft size, arguing that larger aircraft are needed as the distance between two endpoints increases. However, the study only investigated the US airline industry, focusing on determinants for aircraft size and frequency of flights such as market demographics, airport characteristics, airline characteristics, and route characteristics (Pai, 2010).

Although, Givoni and Rietveld (2010) confirmed the general behaviour of airlines in preferring small aircraft and high frequency to larger aircraft and lower frequency on short haul routes, they also highlighted the likelihood of full-service network carriers opting for higher seat densities on their large aircraft when operating them on short-haul hub-to-hub routes. They argued that this occurs due to the low demand for first-class seats on such routes. One example supporting this concept is that of British Airways, where the B767 aircraft fleet in 2016 had more installed seats (259) on its UK domestic routes than on its European routes (244 seats) and its long-haul routes (189 seats) (British Airways, 2016). In addition, to compensate for an increase in seats, a corresponding reduction in belly-freight carried on 
short to medium haul routes is observed. The changes in seat to cargo weight ratios over changing distances underscores the importance of air cargo in long haul airline operations compared to short haul operations (IPCC, 1999).

With respect to longer term fleet planning, the IPCC reported a $1 \%$ per year growth in aircraft size as the current trend (IPCC, 1999). However, this value could be misleading when used for all aircraft types irrespective of the seating capacity. It is equally important to identify the latest value of this variable nearly two decades after it was first determined.

Thus, although these studies have identified that airline business models and route characteristics determine aircraft seat capacities, their area of study was not based on flight connections within and between all world regions. Furthermore, they do not focus on LCCS from across the globe or on an overall majority of the global aircraft fleet.

Two databases are used in this research work. Information on aircraft cabin configurations is obtained from historical databases of scheduled aircraft flights, while airlines are categorised into two main groups - FSNCs and LCCs - by use of a carrier type database. Airlines not belonging to the LCC classification are considered as FSNCs. Although other ABM clusters exist as earlier explained, as there is no comprehensive global database of airlines belonging to these clusters, a simplification in which all airlines are classified into two ABM clusters is adopted.

\subsection{Historical Database of Scheduled Aircraft Flights}

To evaluate the historical development of scheduled aircraft cabin configurations, the Official Airline Guide (OAG) database is used covering information on scheduled flights for years 2000, 2004, 2008, 2012, 2014 and 2016 (OAG, 2000, 2004, 2008, 2012, 2014, 2016). The database was cleaned up by excluding code-share flights, surface transport trips, multi-stop flights and non-aircraft trips.

In selecting the aircraft to be investigated, the aircraft clustering methodology adopted by Randt (2016) was used. Randt developed this methodology for use in longer-term fleet planning studies (Randt, 2016; Randt, Jessberger, \& Ploetner, 2015). In this methodology, the OAG database of 2008 (OAG, 2008) was analysed, then passenger aircraft types listed in the database with a minimum individual share of $0.1 \%$ ASK in the global provision of ASKs were selected. Similarly, freighter aircraft with a minimum individual share of $0.1 \%$ ATKs in the global provision of ATKs were selected. In total, 86 aircraft types were selected that contributed roughly $98 \%$ ASK and ATK of the global ASK and ATK in 2008. Furthermore, using a k-medoids-based clustering tool, the aircraft types were clustered based on available seat and freight capacity, available overall payload capacity, average flight distance flown, and type of propulsion. This resulted in seven clusters of passenger aircraft and two clusters of 
cargo aircraft. As this study is focussed on aircraft seats, the two clusters of cargo aircraft are excluded. The selected clusters and constituent aircraft types are shown in Table 1. Based on the OAG database, the selected aircraft types provided $87 \%$ and $86 \%$ of the total globally planned available seat-kilometres (ASK) in 2000 and 2016 respectively.

Also, based on the OAG classification of world regions, seven main regions were identified, these are: North America (NA1), Europe (EU1, EU2), Latin America (LA1, LA2, LA3, LA4), Africa (AF1, AF2, AF3, AF4), Middle East (ME1), Asia (AS1, AS2, AS3, AS4) and South West (SW1) (Giarratani, Hewings, \& McCann, 2013). The South West region was merged into the Asian region. This is because, unlike the Middle East region, it is more of a destination region than a global aviation intersection. This results in six geographical regions. When considering single-leg flights within the regions as well as between region pairs, 21 route groups result. Thus, the classification of all flights globally into route groups used by Randt (2016) was adopted. This is shown in Figure 1. This classification is used in the definition of regions and route groups1, as later used in this study.

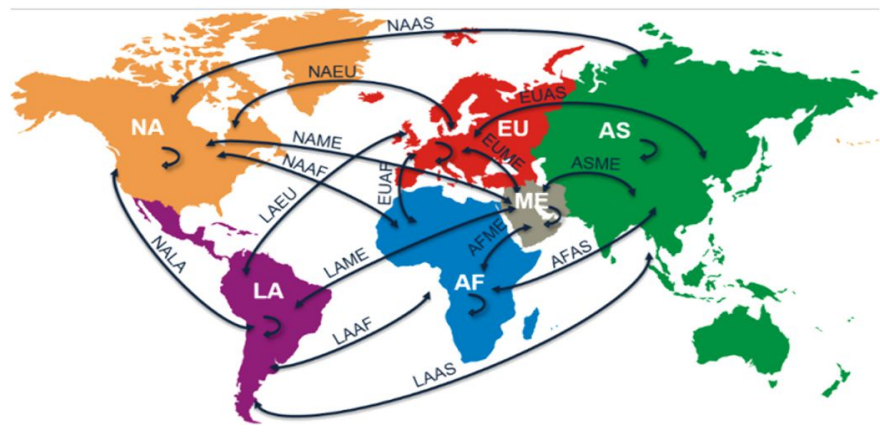

Figure 1. 21 Route groups evaluated, based on Randt (2016)

\subsection{Historical Database of Low-Cost Carriers}

For the evaluation of the historical operation of low-cost carriers (LCCs), a database of LCCs is adopted based on information provided by the International Civil Aviation Organisation (ICAO, 2014). The database was verified to ensure that the IATA codes are correct and further updated for the year 2016 using the ICAO's definition of a low-cost carrier as

"an air carrier that has a relatively low-cost structure in comparison with other comparable carriers and offers low fares and rates. Such an airline may be independent, the division or subsidiary of a major network airline or, in some instances, the ex-charter arm of an airline group" (ICAO, 2013 p.7).

${ }^{1}$ A route group refers to flights within a geographic region or between a pair of regions. 
Table 1. Evaluated aircraft clusters and constituent specific aircraft names (Randt, 2016)

\begin{tabular}{|l|l|}
\hline $\begin{array}{l}\text { Aircraft } \\
\text { Cluster } \\
\text { Name }\end{array}$ & Constituent Aircraft OAG-Specific Aircraft Name \\
\hline $\begin{array}{l}\text { Long-range } \\
\text { Combi (LRC) }\end{array}$ & $\begin{array}{l}\text { Boeing (Douglas) MD-11 Passenger, Boeing747 (Mixed Configuration), Boeing 747-400 } \\
\text { (Mixed Configuration) }\end{array}$ \\
\hline $\begin{array}{l}\text { Long-range } \\
\text { heavy (LRH) }\end{array}$ & $\begin{array}{l}\text { Airbus A380-800 Passenger, Boeing 747 (Passenger), Boeing 747-300/747-100/200 Sud } \\
\text { (Pax), Boeing 747-400 (Passenger), Boeing 777-300 Passenger }\end{array}$ \\
\hline $\begin{array}{l}\text { Jet } \\
\text { commuter } \\
\text { (JC) }\end{array}$ & $\begin{array}{l}\text { Airbus A318, Avro RJ100, Avro RJ85, Boeing 727 (Freighter), Boeing 737 (Freighter), } \\
\text { Boeing 737-200 Passenger, Boeing 737-600 Passenger, Canadair Regional Jet, Canadair } \\
\text { Regional Jet 200, Canadair Regional Jet 700, Canadair Regional Jet 900, Embraer 170, } \\
\text { Embraer 175, Embraer 190, Embraer RJ 135/140/145, Embraer RJ 145, Fokker 100, } \\
\text { Tupolev TU134 }\end{array}$ \\
\hline $\begin{array}{l}\text { Turboprop } \\
\text { commuter } \\
\text { (TC) }\end{array}$ & $\begin{array}{l}\text { ATR 72 } \\
\text { Mid-range } \\
\text { (MR) }\end{array}$ \\
$\begin{array}{l}\text { Airbus A300-600 Passenger, Airbus A310 Passenger, Airbus A330, Airbus A330-300, } \\
\text { Boeing 757 (Passenger), Boeing 757-200 (winglets) Passenger, Boeing 757-200 } \\
\text { Passenger, Boeing 757-300 Passenger, Boeing 767-300 Passenger, Tupolev TU-204 /tu- } \\
214\end{array}$ \\
\hline $\begin{array}{l}\text { Long-range } \\
\text { (LR) }\end{array}$ & $\begin{array}{l}\text { Airbus A330-200, Airbus A340, Airbus A340-200, Airbus A340-300, Airbus A340-500, } \\
\text { 200LR, Boeing 777-300ER, Ilyushin II-96 Passenger }\end{array}$ \\
\hline $\begin{array}{l}\text { Narrow-body } \\
\text { (NB) }\end{array}$ & $\begin{array}{l}\text { Airbus A318 /319/ 320 /321, Airbus A319, Airbus A320, Airbus A321, Boeing (Douglas) } \\
\text { MD-80, Boeing (Douglas) MD-81, Boeing (Douglas) MD-82, Boeing (Douglas) MD-83, } \\
\text { Boeing (Douglas) MD-88, Boeing (Douglas) MD-90, Boeing 717-200, Boeing 737 } \\
\text { Passenger, Boeing 737-300 Passenger, Boeing 737-400 Passenger, Boeing 737-500 } \\
\text { Passenger, Boeing 737-700 (winglets) Passenger, Boeing 737-700 Passenger, Boeing 737- } \\
800 \text { Passenger, Boeing 737-900 Passenger, McD- Douglas DC9 30 /40 /50, Tupolev TU154 }\end{array}$ \\
\hline
\end{tabular}

Table 2. Validation of LCC database

\begin{tabular}{|c|c|c|}
\hline \multirow{2}{*}{ Year } & \multicolumn{2}{|c|}{ LCC Global market share } \\
\hline & Own values (\% difference) & Published values \\
\hline 1997 & \multirow[t]{2}{*}{ ( } & $6 \%$ seats (Airbus, 2008) \\
\hline$\frac{1998}{1999}$ & & $\mathrm{n} / \mathrm{a}$ \\
\hline 2000 & $\begin{array}{l}5 \% \text { ASK, } 37600 \text { flights/week (31\%), } 8 \% \\
\text { seats }\end{array}$ & 28640 flights/week (Magill, 2004) \\
\hline $\begin{array}{ll}2001 \\
2002\end{array}$ & \multirow[t]{2}{*}{ 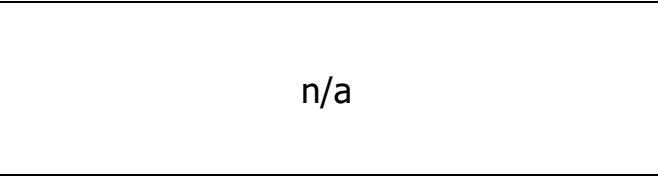 } & $\mathrm{n} / \mathrm{a}$ \\
\hline 2003 & & $\begin{array}{c}\text { 7\% ASK, } 42490 \text { flights/week (Boeing Commercial } \\
\text { Airplanes, 2014; Magill, 2004) }\end{array}$ \\
\hline 2004 & $10 \%$ ASK, 70795 flights/week, $15 \%$ seats & \multirow[b]{2}{*}{$\mathrm{n} / \mathrm{a}$} \\
\hline$\frac{2005}{2006}$ & \multirow[t]{2}{*}{$e^{2}$} & \\
\hline 2007 & & $20 \%$ seats (Airbus, 2008) \\
\hline 2008 & $\begin{array}{c}15 \% \text { ASK, } 109590 \text { flights/week, } 22 \% \\
\text { seats }\end{array}$ & \multirow{4}{*}{$\mathrm{n} / \mathrm{a}$} \\
\hline $\begin{array}{l}2009 \\
2010\end{array}$ & \multirow{2}{*}{$\mathrm{n} / \mathrm{a}$} & \\
\hline 2011 & & \\
\hline 2012 & $25 \%$ seats & \\
\hline 2013 & $\mathrm{n} / \mathrm{a}$ & $\begin{array}{c}26 \% \text { seats, } 16 \% \text { ASK (Boeing Commercial Airplanes, } \\
2014 \text {, Boeing Commercial Airplanes, 2015) }\end{array}$ \\
\hline 2014 & $\begin{array}{c}20 \% \text { ASK, } 149979 \text { flights/week, } 28 \% \\
\text { seats }\end{array}$ & $\mathrm{n} / \mathrm{a}$ \\
\hline 2015 & $\mathrm{n} / \mathrm{a}$ & $28 \%$ seats $(A C I, 2016 ;$ ICAO, 2015) \\
\hline 2016 & $28 \%$ seats $(0 \%)$ & $28 \%$ seats $(I C A O, 2017)$ \\
\hline
\end{tabular}


In updating the database for 2016, airlines listed in the OAG 2016 database which were not included in previous OAG databases were identified and evaluated for compliance to the ICAO LCC definition. Sources consulted in updating the database include airline websites, Ishka (2017), and DLR (2016). Table 2 below shows the results of the validation check on global ASK, flights per week and percentage of total seats flown by LCCs globally, comparing own values with published values. The list of LCCs used in the analysis for the respective years is presented in the appendix.

\section{PRELIMINARY ANALYSIS}

In this section, representative clusters in the small, medium, and large aircraft categories, based on the highest total seats transported, (namely, JC, NB and LR aircraft clusters) are focused on. Similarly, where geographic world regions are discussed, the analysis covers intraregional as well as inter-regional flights for the three biggest regions in terms of total departing seats on intra-regional flights in 2016. The regions are Asia, North America and Europe. Results for all aircraft clusters and route groups are presented in the appendix.

The historical development of seat capacities of the selected aircraft clusters is evaluated for both global and route group dimensions. In addition, the historical development of seat capacities of the aircraft clusters operated by the two ABM clusters is also investigated both for global and route group dimensions.

In computing average annual growth rates over the analysis period for use in longer-term fleet planning, values from each data point or analysis year were assumed to change linearly until the next available data point. Furthermore, in computing average differences in the number of aircraft installed seats over the analysis period, comparing ABMs, values from each data point were assumed to remain constant until the next available data point. To include the effect of flight frequencies, the average seats and average distances shown are weighted by flight frequency. Moreover, for each year and group of flights being analysed, a distinction is made between the average seat capacities scheduled, weighted by flight frequency, and the average maximum possible seat capacity for each aircraft cluster, also weighted by flight frequency. The former was determined from the number of seats on scheduled flights available from the OAG databases, weighted by flight frequency while the latter was analysed by determining the maximum seat capacity possible for each aircraft type analysed in the database and finding the average of these maximum possible values, weighted by flight frequency. 
Sources consulted in determining the maximum seat capacity for each aircraft type include aircraft manufacturer websites2, Pitt \& Norsworthy (2013), DVB Aviation Research (2015) and other sources3. The average maximum possible seat capacity was determined as a reference frame against which values of average scheduled seat capacity are compared, thus accounting for the differences in the mix of aircraft constituting an aircraft cluster for a given analysis year and group of flights. Moreover, given that one maximum possible seat capacity is given for a specific aircraft which was scheduled with a variety of installed seats depending on the airline, the average maximum possible seat capacity metric gives an insight into the prevailing or less prevailing constituent aircraft in each cluster per analysis year. Furthermore, using this metric makes it possible to estimate the aircraft cabin utilisation for each aircraft cluster. Aircraft cabin utilisation is here defined as the ratio, in percent, of the average scheduled seat capacity and the average maximum possible seat capacity for each aircraft cluster.

\subsection{Historical Global Development of Aircraft Cluster Seat Capacities}

Over the 17-year analysis period, aircraft cabin utilisation was found to grow at average annual growth rates of $0.4 \%, 0.6 \%$ and $0.5 \%$ for the JC, LR and NB aircraft clusters respectively. There was also an increase in the average number of installed seats on the three aircraft clusters. Average annual growth rates of $0.6 \%, 1.1 \%$, and $0.3 \%$ were found for the JC, NB, and LR aircraft clusters respectively. Considering maximum possible seat capacity within the JC and NB clusters, there was a shift to larger dominant constituent aircraft types with larger maximum possible seat capacities since average maximum possible seat capacity increased at average annual growth rates of $0.2 \%$ and $0.5 \%$ respectively between 2000 and 2016 . On the other hand, average maximum possible seat capacity for the LR cluster decreased at about $0.2 \%$ per year between 2000 and 2016. This development can be seen in Figure 2 below.

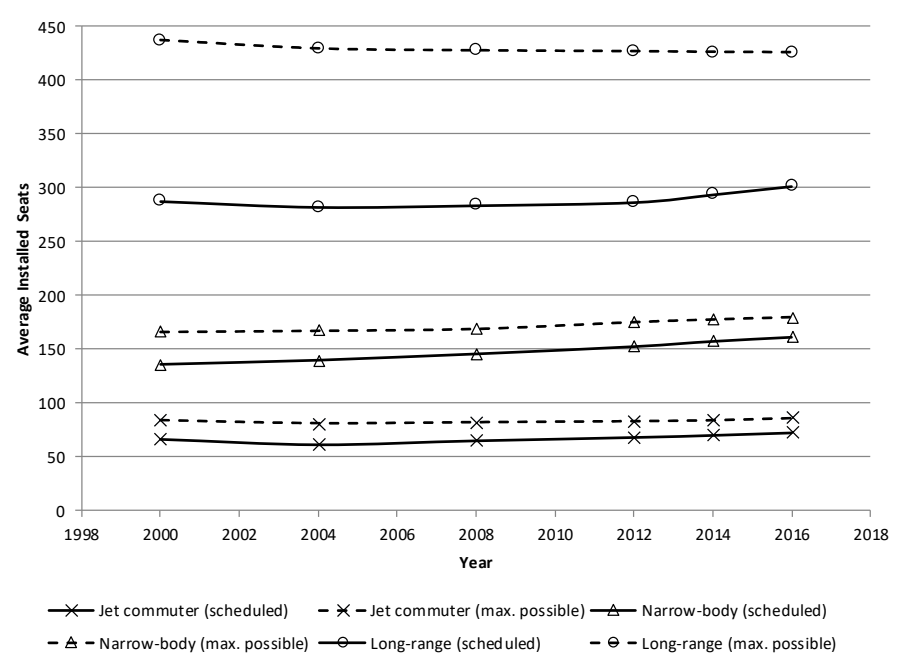

Figure 2. Global development of aircraft cluster seat capacities, scheduled and maximum possible

\footnotetext{
2 For Airbus, Boeing, Bombardier, Embraer, Fokker, Ilyushin, and Tupolev aircraft

${ }^{3}$ www.airliners.net and www.angelwingsva.com
} 
Therefore, the strong growth of the NB aircraft cluster average maximum possible seat capacity reflects the penetration of larger variants of the B737 and A320 family in the global fleet market. On the other hand, the decrease in the LR aircraft cluster average maximum possible seat capacity suggests a shift to, or prevalence of, constituent aircraft of the aircraft cluster with lower maximum possible seat capacities. For example, there could be less prevalence of the A340 and Boeing 777-300ER and more of the A330-200 and B777-200 aircraft. It is to be noted that although average maximum possible seat capacity of the LR aircraft reduced, the average distance flown by the aircraft cluster fleet increased over the analysis period.

\subsection{Differences in Aircraft Seat Capacities Depending on Airline Business Models}

In addition to determining the developments in average aircraft cluster seat capacity (scheduled and maximum possible) over time, these developments were also evaluated based on airline business models. Figure 3 presents the average maximum possible seat capacities of the three aircraft clusters as operated by the two ABM clusters over the analysis period. The results show that the average maximum possible seat capacities of NB and LR aircraft used by LCCs were $7 \%$ and $5 \%$ lower than those operated by FSNCs, whereas the maximum possible seat capacities of JC aircraft of LCCs are higher than those of FSNCs. This implies that globally, LCCs operated smaller constituent aircraft4 of the NB and LR aircraft clusters compared to FSNCs, whereas FSNCs operated smaller constituent aircraft of the JC cluster as compared to LCCs.

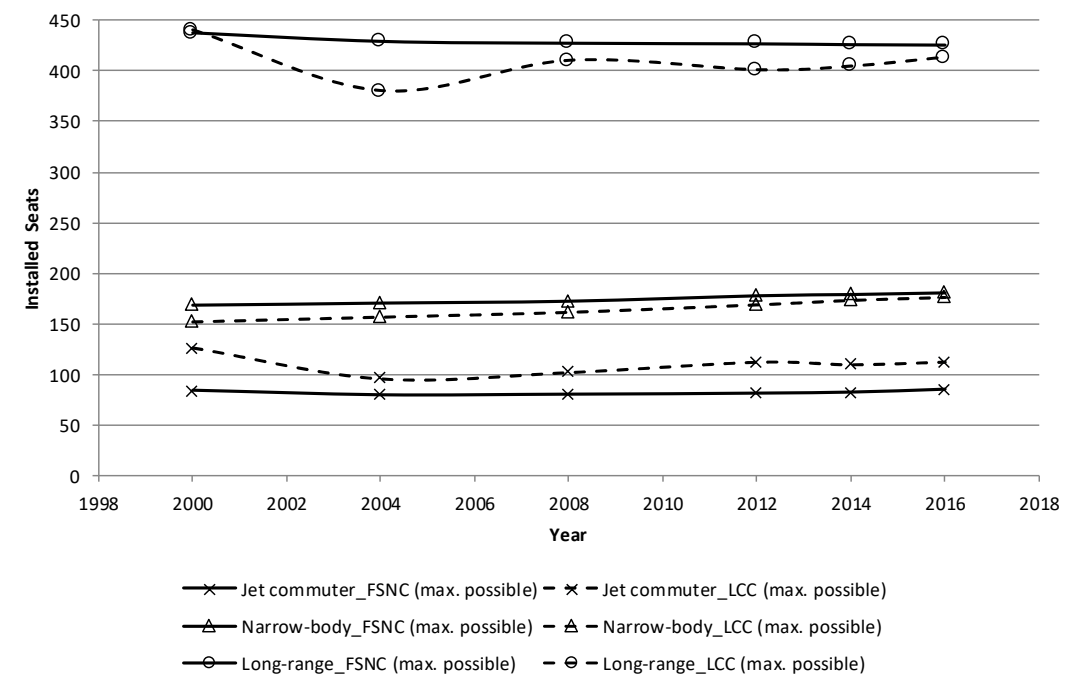

Figure 3. Global development of aircraft cluster average maximum possible seat capacities, FSNCs and LCCS 
In addition, Figures 4 and 5 present the historical development in seat capacities and aircraft cabin utilisation of the selected aircraft clusters as operated by FSNCs and LCCs, respectively, within the analysis period.

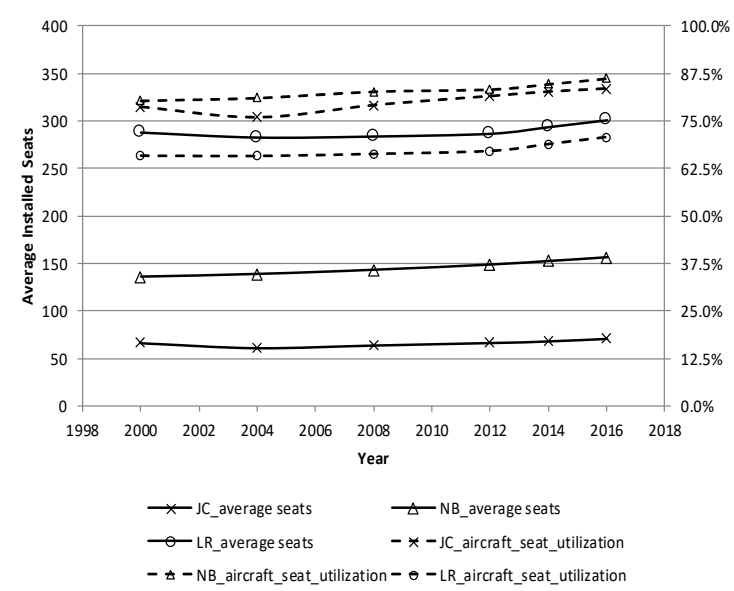

Figure 4. Global development of FSNC aircraft cluster seat capacities and cabin utilisation

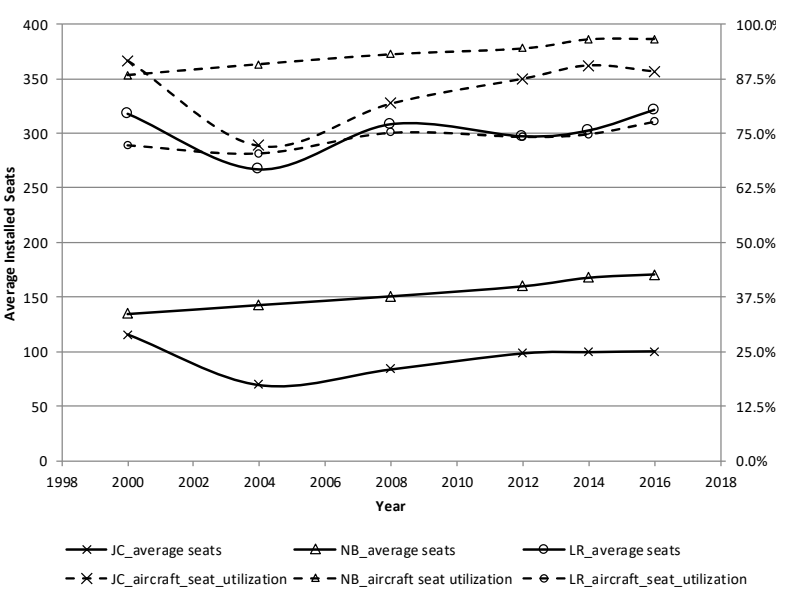

Figure 5. Global development of LCC aircraft cluster seat capacities and cabin utilisation

Therefore, although the average maximum possible seat capacities of NB and LR aircraft operated by LCCs were less than those operated by FSNCs, LCCs still installed more seats on their "smaller" aircraft than the number of seats installed by FSNCs on their "larger" NB and LR aircraft. Furthermore, LCCs operated JC aircraft that were larger on average (i.e. aircraft with greater maximum possible seat capacity) and installed more seats than FSNCs.

Considering installed seats per cabin class, for the JC and NB there was an increase in the share of first class and business class seats ( $F+C$ seats) of FSNCs, whereas the reverse was found for LCCs. The share of economy seats on these two aircraft clusters was about $92 \%$ and 99\% for FSNCs and LCCs, respectively in 2016.

However, for the LR aircraft cluster, there was a growth in the share of premium seats for the two ABMs until 2008 after which the share of these seats slightly reduced for both business models. This is in agreement with a CAPA report that claimed a loss of share in premium traffic relative to economy traffic since the 2009 recession (CAPA, 2013). The share of economy seats in the LR aircraft cluster was about $87 \%$ and $94 \%$ for FSNCs and LCCS, respectively in 2016. This confirms the reduced focus of LCCs on business passengers in comparison with FSNCs over their operated routes. The development in the share of premium seats ( $F+C$ seats) and economy seats ( $Y$ seats) on LR aircraft operated by the two ABM clusters is presented in Figure 6. 


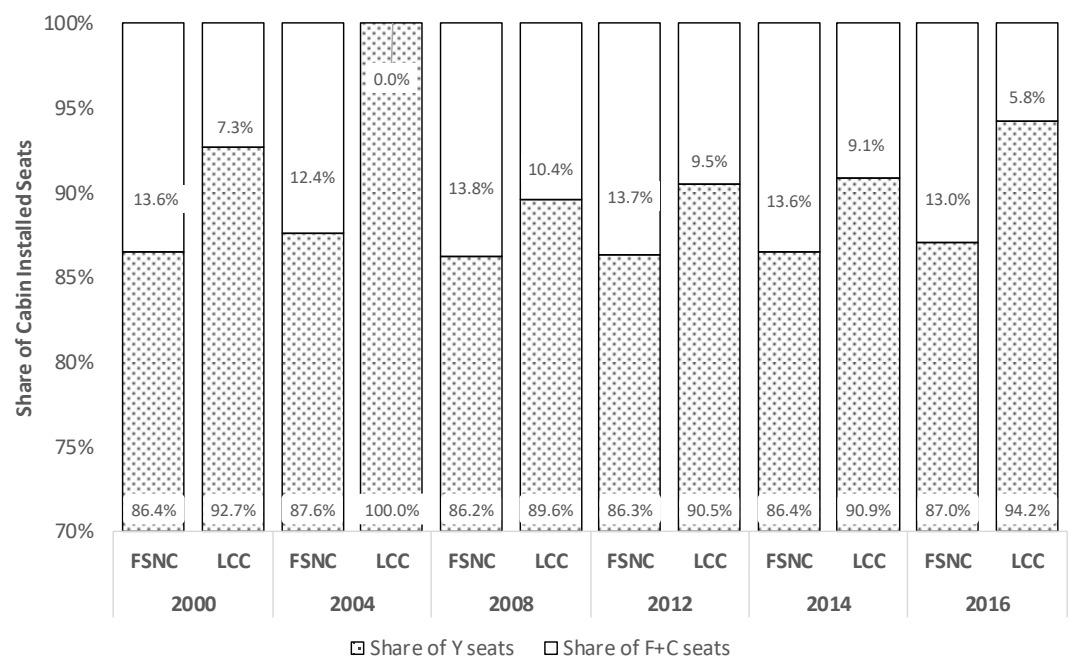

Figure 6. Globally installed seats per cabin class on LR aircraft by FSNCs and LCCS

\subsection{Historical Development of Aircraft Cluster Seat Capacities between and within Geographical Regions and Airline Business Models}

Frequency-weighted average scheduled and maximum possible seats of the evaluated aircraft clusters operating the selected inter-regional and intra-regional flights from 2000 to 2016 are shown in Appendices 8 and 9. The corresponding average annual growth rates in average installed seats are shown in Table 3.

Over the 17-year period, for the three aircraft clusters considered, the highest average annual growth rate in aircraft seat capacity was found on intra-European flights. However, the average maximum possible seat capacity did not increase accordingly. As a result, for the three aircraft clusters, the highest cabin utilisation on intra-regional flights was in Europe. (see Appendix 5).

In addition, the highest average scheduled seat capacities on aircraft belonging to the JC and NB aircraft clusters were found in Europe, while the highest scheduled seat capacity on aircraft belonging to the long-range aircraft cluster was found on flights in Asia. This reflects the contribution of high-density short haul routes within Asia. On the other hand, the lowest average annual growth rate summed up for the three clusters was on flights in Asia.

On inter-regional routes, where the long-range aircraft cluster is designed to operate, a growth in the average installed seats was also observed over the analysis period. The highest annual growth rate for the LR and NB aircraft cluster was on North Atlantic or North America-Europe routes with an average of $0.8 \%$, while the lowest was on Trans Pacific or Asia-North America routes with an average of $0.5 \%$. In addition, LR aircraft on Trans Pacific routes had more seats (average scheduled and maximum possible) than comparable aircraft on North Atlantic routes. These results correspond to historic and forecast trends in aircraft installed seats presented by the IPCC for these routes (IPCC, 1999). Focusing more on inter-regional flights 
using LR aircraft, Figure 7 below the development of average scheduled seats and average maximum possible installed seats for the LR aircraft cluster (both weighted by frequency) with distance flown (also weighted by frequency), when operating intra- and inter-regional flights for the Asian, North American and European geographical regions. The average number of scheduled seats, weighted by frequency, on LR aircraft was more when operating intraregional flights than when operating inter-regional flights. However, the average maximum possible seat capacity was higher on inter-regional flights than on intra-regional flights. This result reflects the strategy identified previously in which airlines install more seats on their wide-body aircraft when flying shorter missions, whereas less seats are installed for longerrange missions to enable the transport of more belly-cargo. This correlation was not observed for the jet commuter and narrow-body clusters.

Table 3. Average annual growth rates in aircraft cluster seat capacity between 2000 and 2016, all airlines

\begin{tabular}{|c|c|c|c|}
\hline Route Group & $\begin{array}{l}\text { Aircraft } \\
\text { Cluster }\end{array}$ & $\begin{array}{c}\text { Average Annual } \\
\text { Growth Rate 2000- } \\
2016[\%]\end{array}$ & $\begin{array}{c}\text { Average Annual } \\
\text { Growth Rate 2008- } \\
2016[\%]\end{array}$ \\
\hline \multirow[t]{3}{*}{ Intra North America } & $\mathrm{JC}$ & 0.7 & 1.1 \\
\hline & NB & 0.8 & 1.4 \\
\hline & LR & 0.4 & 0.3 \\
\hline \multirow[t]{3}{*}{ Intra Europe } & $\mathrm{JC}$ & 1.4 & 2.4 \\
\hline & NB & 1.2 & 1.3 \\
\hline & LR & 1.0 & 0.8 \\
\hline \multirow[t]{3}{*}{ Intra Asia } & $\mathrm{JC}$ & -0.7 & 1.6 \\
\hline & NB & 0.8 & 1.2 \\
\hline & LR & -0.4 & 0.5 \\
\hline \multirow{3}{*}{$\begin{array}{l}\text { North America- } \\
\text { Europe }\end{array}$} & $\mathrm{JC}$ & -6.1 & -6.1 \\
\hline & NB & 1.1 & 7.3 \\
\hline & LR & 0.5 & 0.5 \\
\hline \multirow[t]{3}{*}{ Europe-Asia } & $\mathrm{JC}$ & -1.1 & -2.2 \\
\hline & NB & 0.6 & 1.6 \\
\hline & LR & 0.6 & 0.2 \\
\hline \multirow[t]{3}{*}{ Asia-North America } & $\mathrm{JC}$ & 0 & 0 \\
\hline & NB & 0.5 & 1.9 \\
\hline & LR & 0.5 & 0.2 \\
\hline
\end{tabular}

Analysing the developments in installed seats over time, geographic region, and airline business models, the development of average scheduled aircraft cluster seat operated by FSNCs and LCCs over time on intra-regional routes is presented in Appendices 10 to 13. In addition, Table 4 shows the development in aircraft cluster average seat capacities over the analysis period.

In 2016, LCCs had a market share of $41 \%, 32 \%$, and $24 \%$ on European, North American and Asian regional flights, respectively. From Table 4, it can be seen that LCCs had different approaches to competing with FSNCs in terms of increasing the number of seats on their 
aircraft between 2000 and 2016 on the 3 intra-regional routes. For example, within North America, they operated the single-aisle cluster aircraft while at least matching the growth rate of the FSNCs. Within Europe, LCCs reduced growth in JC aircraft seats while ensuring slightly higher growth in NB cluster seats, while within Asia they doubled the growth rate of NB cluster seats compared to FSNCs. Where the LR cluster is concerned, LCCs maximised growth in average scheduled seats in Asia while no growth occurred in this cluster in the other two route groups.

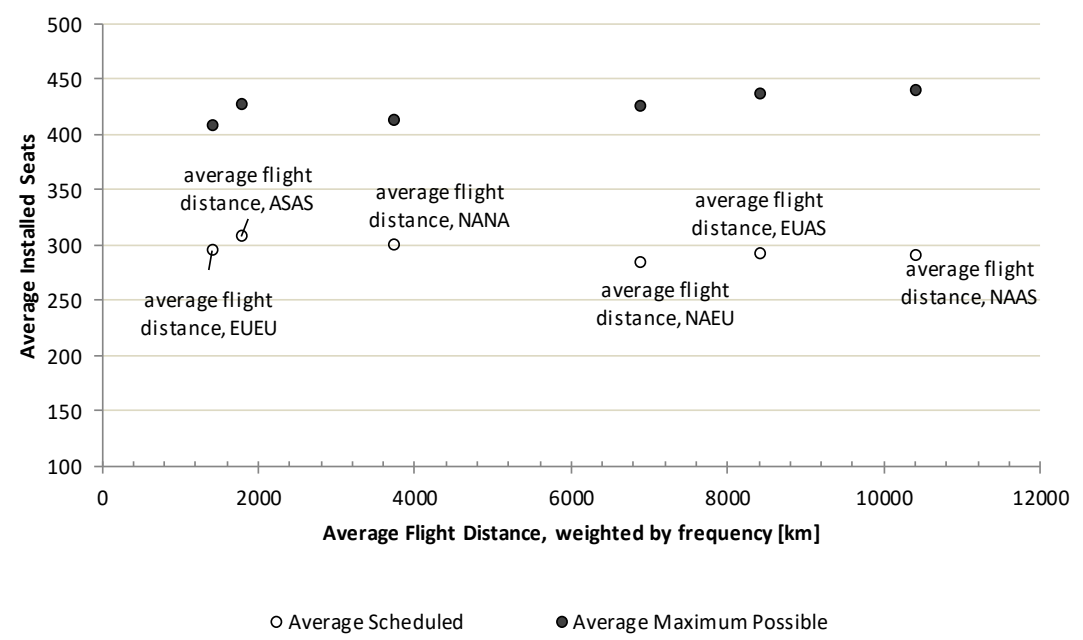

Figure 7. Development of average and maximum possible seat capacities with flight distance, for selected inter- and intra-regional flights using LR aircraft cluster in 2016

The historical development in the seat share of FSNCs and LCCS on intercontinental routes between the three regions is shown in Figure 8 while Table 5 shows the corresponding average annual growth rates on the route groups. From Figure 8, over the analysis period, LCCs had a lower but increasing market share on these inter-regional route groups, with the highest market share being on North Atlantic routes. In 2016, LCCs had a market share of 3.9\%, $1.6 \%$, and $0.4 \%$ on the North Atlantic, European-Asian and Trans Pacific routes respectively.

LCCs did not operate JC aircraft on the three inter-regional routes due to the payload-range limitation of the aircraft cluster. However, this aircraft cluster was operated by FSNCs on Europe-Asia routes. Furthermore, in the study of the differences in installed seats by the different $A B M s$ on these inter-regional routes, the focus is on LR aircraft since the design characteristics of this aircraft cluster is most suitable for both ABMs operating on these three routes. Table 5 shows the average annual growth rates of average seat capacity of aircraft belonging to the LR cluster operated by the different ABMs on the observed route groups.

Similar to the observation made concerning intra-regional flights, LCCs operate their LR cluster aircraft with different configurations on the different inter-regional route groups. On the North 
Atlantic market, LCCs grew their market share from $0.2 \%$ in 2000 to $3.9 \%$ in 2016 . They also operated LR aircraft with about 14\% more seats than LR aircraft operated by FSNCs, using constituent aircraft with $2 \%$ higher average maximum possible seat capacity.

Table 4. Average annual growth rates in aircraft cluster seat capacity of FSNCs and LCCs on regional routes, between 2000 and 2016

\begin{tabular}{|c|c|c|c|}
\hline $\begin{array}{c}\text { Route } \\
\text { Group }\end{array}$ & $\begin{array}{c}\text { Aircraft } \\
\text { Cluster- } \\
\text { ABM }\end{array}$ & $\begin{array}{c}\text { Average Annual Growth } \\
\text { Rate 2000-2016 [\%] }\end{array}$ & $\begin{array}{c}\text { Average Annual } \\
\text { Growth Rate 2008- } \\
\text { 2016 [\%] }\end{array}$ \\
\hline Intra North & JC-FSNC & 0.5 & 1.1 \\
\cline { 2 - 4 } America & JC-LCC & 0.6 & 2.4 \\
\cline { 2 - 4 } & NB-FSNC & 0.8 & 1.3 \\
\cline { 2 - 4 } & NB-LCC & 0.8 & 1.4 \\
\cline { 2 - 4 } & LR-FSNC & 0.4 & 0.3 \\
\cline { 2 - 4 } & LR-LCC & 0 & 0 \\
\hline \multirow{4}{*}{ Intra } & JC-FSNC & 1.4 & 2.3 \\
\cline { 2 - 4 } & JC-LCC & -0.3 & 3.0 \\
\cline { 2 - 4 } & NB-FSNC & 1.0 & 1.3 \\
\cline { 2 - 4 } & NB-LCC & 1.3 & 0.8 \\
\cline { 2 - 4 } & LR-FSNC & 1.0 & 0.8 \\
\cline { 2 - 4 } & LR-LCC & 0.0 & -12.3 \\
\hline \multirow{4}{*}{ Intra } & JC-FSNC & -0.5 & 3.6 \\
\cline { 2 - 4 } & JC-LCC & 0 & 0 \\
\cline { 2 - 4 } & NB-FSNC & 0.6 & 1.0 \\
\cline { 2 - 4 } & NB-LCC & 1.2 & 0.5 \\
\cline { 2 - 4 } & LR-FSNC & -0.5 & 4.5 \\
\cline { 2 - 4 } & LR-LCC & 4.2 & \\
\hline
\end{tabular}

On Europe-Asia inter-regional routes, LCCs increased their market share from $0.3 \%$ in 2000 to $1.6 \%$ in 2016 . They operated LR aircraft with $3 \%$ less seats on average than FSNCs. They use constituent aircraft with about $5 \%$ less average maximum possible seats than those of LR aircraft operated by FSNCs. LCCs also increased the seat capacities of their LR aircraft by $1.8 \%$ as compared to FSNCs with average annual growth rates of $0.6 \%$. In the Trans-Pacific market segment, LCCs operated LR aircraft at 35\% higher seat capacity than LR aircraft operated by FSNCs, using constituent aircraft with equal average maximum possible seat capacity to those operated by FSNCs. 


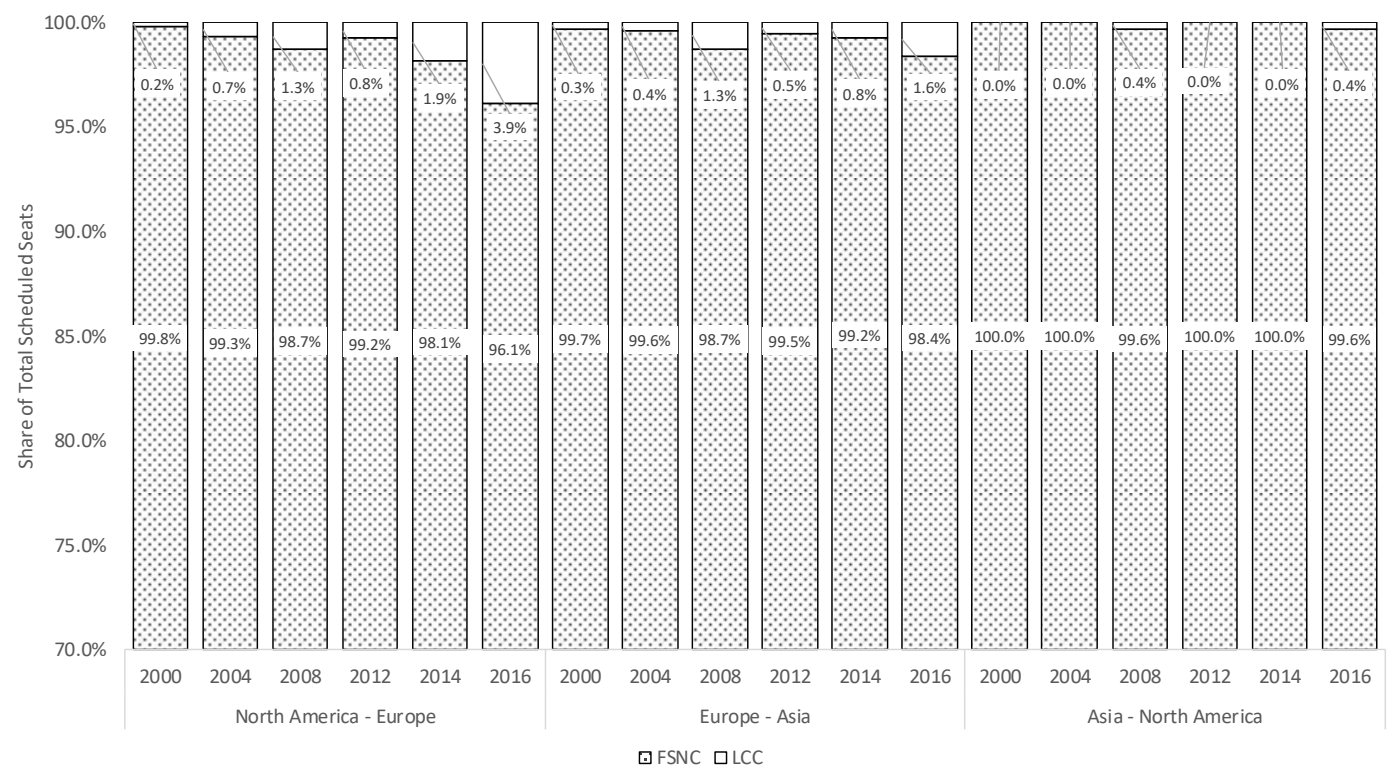

Figure 8. Historical development of inter-regional routes seat share, FSNCs and LCCS

Table 5. Average annual growth rates in LR aircraft seat capacity on inter-regional routes between 2000 and 2016, FSNCs and LCCs

\begin{tabular}{|c|c|c|c|}
\hline $\begin{array}{c}\text { Route } \\
\text { Group }\end{array}$ & $\begin{array}{c}\text { Aircraft } \\
\text { Cluster_ABM }\end{array}$ & $\begin{array}{c}\text { Average Annual } \\
\text { Growth Rate 2000- } \\
\text { 2016 [\%] }\end{array}$ & $\begin{array}{c}\text { Average Annual } \\
\text { Growth Rate 2008- } \\
\text { 2016 [\%] }\end{array}$ \\
\hline $\begin{array}{c}\text { North } \\
\text { America - } \\
\text { Europe }\end{array}$ & LR_FSNC & 0.5 & 0.5 \\
\cline { 2 - 4 } & LR_LCC & 0.4 & 0.4 \\
\hline $\begin{array}{c}\text { Europe- } \\
\text { Asia }\end{array}$ & LR_FSNC & 0.6 & 0.3 \\
\cline { 2 - 4 } & LR_LCC & 1.8 & 3.7 \\
\hline $\begin{array}{c}\text { Asia - North } \\
\text { America }\end{array}$ & LR_FSNC & 0.5 & 0.1 \\
\cline { 2 - 4 } & LR_LCC & 0 & 0 \\
\hline
\end{tabular}

Therefore, in general, LCCs operated their LR aircraft with an average of $15 \%$ higher seat capacity than LR aircraft operated by FSNCs. They also used constituent aircraft with $1 \%$ less maximum possible seats than LR aircraft operated by FSNCs on these inter-regional routes. However, at a route group level, LCCs had different approaches to competing with FSNCs in terms of increasing the number of seats on their aircraft between the analysis period.

\section{HYPOTHESIS-DRIVEN DATA ANALYSIS}

In this section, selected results from the previous section are analysed using statistical tests on the mean. Statistical tests on the means are used to verify statistical significance while drawing conclusions regarding differences in means of average maximum possible seats and average scheduled seats of LCCS and FSNCs. The tests are conducted first for the ABMs generally, then by aircraft cluster. Furthermore, a regression analysis is carried out to determine the variables that significantly affect cabin utilisation of the aircraft clusters. 
In carrying out this analysis, a unit of observation is defined as the average aircraft cluster flight per year, airline business model, and geographic route group. This means that averages of the seat capacities, maximum possible seat capacities, and flight distances are obtained for all scheduled flights by constituent aircraft types in each aircraft cluster, as well as between several specific airport pairs in each route group and between airlines in each ABM cluster.

Entries for an average aircraft cluster flight include average scheduled seats and average maximum possible seat capacities, average utilisation, aircraft operator ABM, and average distance per flight on the 21 identified route groups. In this case, average utilisation refers to the ratio between average scheduled seats and average maximum possible seat capacity of the aircraft cluster. The analysis covers all seven passenger aircraft clusters. Average aircraft cluster flight entries with flight distance exceeding the possible limit stipulated by payloadrange diagrams of aircraft are deleted. Entries with missing or zero seat capacities are also deleted.

\subsection{Difference in seat capacities of LCC and FSNC aircraft, general}

First, a two-sample t-test of average scheduled seats and average maximum possible seats comparing LCCs with FSNCs, using unequal variances, is conducted. This is irrespective of aircraft cluster operated in the average flight. The results suggest that LCCs use aircraft with substantially less scheduled seats than FSNCs. This is only statistically provable up to $90 \%$ confidence interval. In addition, LCCs use aircraft that have less average maximum possible seats than FSNCs. These are summarised in Tables 6 and 7.

Table 6. Summary result: t-test of average scheduled seats

\begin{tabular}{|c|c|c|c|c|c|c|}
\hline Group & Obs. & Mean & Std. Err. & Std. Dev. & \multicolumn{2}{|c|}{$\begin{array}{l}\text { [90\% Conf. } \\
\text { Interval] }\end{array}$} \\
\hline FSNC & 645 & 226.704 & 4.248 & 107.882 & 219. 707 & 233.701 \\
\hline LCC & 247 & 212.606 & 6.190 & 97.285 & 202.386 & 222.827 \\
\hline combined & 892 & 222.80 & 3.522 & 105.19 & 217.001 & 228.599 \\
\hline diff & & 14.097 & 7.861 & & 1.153 & 27.041 \\
\hline \multicolumn{5}{|c|}{ diff $=$ mean $(F S N C)-$ mean $(L C C)$} & \multicolumn{2}{|c|}{1.793} \\
\hline \multicolumn{5}{|l|}{$\begin{array}{c}\text { Ho: diff }= \\
0\end{array}$} & \multicolumn{2}{|c|}{$\begin{array}{c}\text { degrees of freedom }= \\
890 \\
\text { Ha: diff }>0 \\
\operatorname{Pr}(T>t)=0.037\end{array}$} \\
\hline
\end{tabular}


Table 7. Summary result: t-test of average maximum possible seat capacity

\begin{tabular}{|c|c|c|c|c|c|c|}
\hline Group & Obs. & Mean & Std. Err. & Std. Dev. & \multicolumn{2}{|c|}{$\begin{array}{l}\text { [95\% Conf. } \\
\text { Interval] }\end{array}$} \\
\hline FSNC & 645 & 343.243 & 7.124 & 180.937 & 329.253 & 357.233 \\
\hline $\mathrm{LCC}$ & 247 & 270.928 & 9.290 & 146.008 & 252.629 & 289.226 \\
\hline combined & 892 & 323.218 & 5.857 & 174.919 & 311.724 & 334.713 \\
\hline diff & & 72.315 & 12.870 & & 47.057 & 97.573 \\
\hline \multicolumn{5}{|c|}{ diff $=$ mean $(F S N C)-$ mean $(L C C)$} & \multicolumn{2}{|c|}{$=5.619 \quad \mathrm{t}$} \\
\hline $\begin{array}{l}\text { Ho: diff }= \\
0 \\
\text { Ha: di } \\
\operatorname{Pr}(T<t)\end{array}$ & $\begin{array}{c}\text { Ho: } \operatorname{diff}= \\
0\end{array}$ & & $\begin{array}{l}\text { Ha: diff }=0 \\
T|>| t \mid)=\end{array}$ & & \multicolumn{2}{|c|}{$\begin{array}{c}\text { degrees of freedom }= \\
890 \\
H a: \text { diff }>0 \\
\operatorname{Pr}(T>t)=0.000\end{array}$} \\
\hline
\end{tabular}

4.2 Difference in cabin utilisation and seat capacities of LCCS and FSNCS, by aircraft cluster Two-sample t-tests of average maximum possible seats comparing LCCs with FSNCs, using equal variances, are conducted for each aircraft cluster. The results are summarised in Table 8 below.

Table 8. Summary result: t-test of maximum possible seats, LCCs and FSNCs

\begin{tabular}{|c|c|c|c|c|c|}
\hline $\begin{array}{c}\text { Aircraft } \\
\text { Cluster }\end{array}$ & $\begin{array}{c}\text { Mean } \\
\text { maximum } \\
\text { possible } \\
\text { seats FSNC }\end{array}$ & $\begin{array}{c}\text { Mean } \\
\text { maximum } \\
\text { possible } \\
\text { seats LCC }\end{array}$ & $\begin{array}{c}\text { Mean } \\
\text { difference }\end{array}$ & $\begin{array}{c}\text { p value } \\
\text { mean (FSNC)- } \\
\text { mean (LCC) =0 }\end{array}$ & 95\% C.I. \\
\hline TC & 74 & 74 & 0 & $x$ & $(0,0)$ \\
\hline JC & 91 & 106 & -15.3 & 0.0000 & $(-22.3,-8.4)$ \\
\hline NB & 178 & 175 & 2.4 & 0.1416 & $(-0.2,5.1)$ \\
\hline MR & 344 & 331 & 12.3 & 0.0777 & $(-1.4,26.1)$ \\
\hline LRC & 457 & 410 & 47.5 & $x$ & $x$ \\
\hline LR & 424 & 408 & 15.6 & 0.0074 & $(4.4,26.9)$ \\
\hline LRH & 604 & 619 & -15.2 & 0.0074 & $(-25.8,-4.5)$ \\
\hline x: not available & \multicolumn{5}{l}{} \\
\hline
\end{tabular}

Although, LCCs are known to use significantly smaller (average maximum possible seat capacity) aircraft types than FSNCs, the results in Table 8 give more information into this relation by analysing the aircraft clusters individually. FSNCs use significantly bigger aircraft types than LCCs, in the LR cluster. This is probably because the latter try to minimise their landing costs, as part of their cost-minimization strategy. On the other hand, within a 95\% CI, LCCs use significantly bigger aircraft types in JC clusters than FSNCs. LCCs could be said to also use bigger LRH aircraft than FSNC, but this cannot be statistically proven since only 16 observations are available to show this. Interestingly, given that the NB aircraft cluster embodies the main aircraft types of LCCs at least in Europe (EUROCONTROL, 2017), the results for this aircraft cluster are not significant. Although FSNCs have higher average maximum possible seats than LCCS, this difference is not statistically significant. As expected, 
LCCs have significantly more seats than FSNCs when using aircraft in clusters JC, NB, MR, and LR. These are also the main aircraft types in use by LCCs. The other clusters could be operated by LCCS, but only on rare occasions.

Evaluating the cabin utilisation behaviour of the two business models, LCCs have a significantly higher cabin utilisation than FSNCs for aircraft in the NB, MR, and LR clusters. A lower cabin utilisation by FSNCs hints towards the fact that they have a higher passenger comfort through a higher share of premium seats on aircraft in these clusters than LCCs.

Table 9. Summary result: t-test of mean cabin utilisation, LCCs and FSNCs

\begin{tabular}{|c|c|c|c|c|c|}
\hline $\begin{array}{c}\text { Aircraft } \\
\text { Cluster }\end{array}$ & $\begin{array}{c}\text { Mean } \\
\text { cabin } \\
\text { utilisation } \\
\text { FSNC }\end{array}$ & $\begin{array}{c}\text { Mean } \\
\text { cabin } \\
\text { utilisation } \\
\text { LCC }\end{array}$ & $\begin{array}{c}\text { Mean } \\
\text { difference }\end{array}$ & $\begin{array}{c}\text { p value } \\
\text { mean (FSNC) - } \\
\text { mean (LCC)=0 }\end{array}$ & 95\% C.I. \\
\hline TC & 0.929 & 0.938 & -0.008 & 0.439 & $(-0.03,0.01)$ \\
\hline JC & 0.848 & 0.883 & -0.035 & 0.101 & $(-0.08,0.01)$ \\
\hline NB & 0.817 & 0.910 & -0.093 & 0.000 & $(-0.11,-0.07)$ \\
\hline MR & 0.661 & 0.774 & -0.113 & 0.000 & $(-0.13,-0.09)$ \\
\hline LRC & 0.611 & 0.707 & -0.096 & $x$ & $(-0.11,-0.05)$ \\
\hline LR & 0.666 & 0.742 & -0.076 & 0.000 & $(-0.10,-0.03)$ \\
\hline LRH & 0.612 & 0.680 & -0.067 & 0.001 & \\
\hline x: not available
\end{tabular}

\subsection{Regression model of average cabin utilisation per aircraft cluster}

Innovations in aircraft design like Cabin Flex (Saab Press Center, 2015) and in aircraft interior design like Space Flex (Dron, 2015) and Smart Cabin Reconfiguration (Rahner, 2017) are developed and advertised to offer flexibility in or optimization of aircraft cabin utilisation. This implies that in addition to the revenue and profit generated by use of their aircraft, fleet planners also evaluate their strategies in terms of cabin utilisation. However, there has been little or no work done in estimating the predictors of aircraft cabin utilisation, compared to aircraft seating capacity. To support our previous findings, a simple regression model is constructed. The model estimates the effect of two variables of interest (distance and $A B M$ ) on our dependent variable cluster cabin utilization. From the definition of cabin utilization, a value above unity cannot exist. Furthermore, the regression analysis assumes a lower bound of 0.5 for the dependent variable. Furthermore, effects of control variables (route groups and years of observation) are included. Based on literature findings (Boeing Commercial Airplanes, 2017; Givoni \& Rietveld, 2009), these control variables also have an impact on aircraft cabin utilisation. The variables are defined in Table 10, while the descriptive statistics of the variables are shown in Table 11. Three models are estimated via the OLS estimator, using robust standard errors. More variables are added in each new model to test their effect on the 
identified regression relationship of the previous model. Table 12 shows the results of the regression models. The main linear equation can be written as:

$$
\text { cabin utilization }=\beta_{0}+\beta_{1} \ln \text { dist }+\beta_{2} L C C
$$

where cabin utilization refers to the cabin utilization of an aircraft cluster; dist stands for the average distance flown by an aircraft cluster; and LCC is a dummy which stands for the operator ABM being LCC. A log-linear relationship is assumed between distance and cabin utilization similar to the approach of Givoni \& Rietveld (2009). The betas are coefficients of the predictors to be estimated.

Table 10. Description of variables

\begin{tabular}{|l|l|l|}
\hline Variable & Definition & Source \\
\hline Aircraft cluster & $\begin{array}{l}\text { An aircraft cluster is a hypothetical aircraft type with } \\
\text { properties such as average scheduled seats, maximum } \\
\text { possible seat capacity, and flight distance averaged } \\
\text { (flight frequency weighted over corresponding } \\
\text { properties of constituent aircraft types. An aircraft } \\
\text { cluster observation can be differentiated from another, } \\
\text { composed of either the same or another set of } \\
\text { constituent aircraft types, based on other properties } \\
\text { like operating airline's business model, the origin and } \\
\text { destination region pair, and the year of observation }\end{array}$ & See Table \\
\hline cabin utilization & $\begin{array}{l}\text { Ratio of average maximum possible seat capacity and } \\
\text { average scheduled seats of aircraft cluster }\end{array}$ & $\begin{array}{l}\text { Own } \\
\text { computation }\end{array}$ \\
\hline distance & $\begin{array}{l}\text { Average flight distance of aircraft cluster, in kilometers } \\
\text { OAG Scheduled } \\
\text { flights database }\end{array}$ \\
\hline LCC & $\begin{array}{l}\text { Dummy, takes a unitary value when operator of cluster } \\
\text { aircraft is LCC }\end{array}$ & $\begin{array}{l}\text { ICAO LCC } \\
\text { database }\end{array}$ \\
\hline $\begin{array}{l}\text { Average } \\
\text { scheduled seats }\end{array}$ & Average scheduled seats of aircraft cluster & $\begin{array}{l}\text { OAG Scheduled } \\
\text { flights database }\end{array}$ \\
\hline $\begin{array}{l}\text { Average } \\
\text { maximum } \\
\text { possible seats }\end{array}$ & $\begin{array}{l}\text { Average maximum possible seat capacity of aircraft } \\
\text { cluster }\end{array}$ & $\begin{array}{l}\text { Various sources, } \\
\text { see appendix }\end{array}$ \\
\hline $\begin{array}{l}\text { Year of } \\
\text { observation }\end{array}$ & $\begin{array}{l}\text { All years of observation in scheduled flight database } \\
\text { used }\end{array}$ & $\begin{array}{l}\text { OAG Scheduled } \\
\text { flights database }\end{array}$ \\
\hline $\begin{array}{l}\text { Route Group } \\
\text { Index }\end{array}$ & Index identifying route group & Own assumption \\
\hline
\end{tabular}

Table 11. Descriptive statistics of the variables

\begin{tabular}{|l|c|c|c|c|c|}
\hline Variable & Observations & Mean & Std. Dev. & Min. & Max. \\
\hline Cabin utilisation & 878 & 0.7521 & 0.1267 & 0.5328 & 1 \\
\hline Distance & 878 & 7.7636 & 1.0297 & 5.0015 & 9.6472 \\
\hline LCC & 878 & 0.2813 & 0.4499 & 0 & 1 \\
\hline $\begin{array}{l}\text { Average scheduled } \\
\text { seats }\end{array}$ & 878 & 224.5579 & 104.3599 & 11.0502 & 480 \\
\hline $\begin{array}{l}\text { Average maximum } \\
\text { possible seats }\end{array}$ & 878 & 321.724 & 174.5599 & 12.8030 & 635.6649 \\
\hline Year & 878 & 2009.251 & 5.5690 & 2000 & 2016 \\
\hline Route Group index & 878 & 11.2551 & 5.7358 & 1 & 21 \\
\hline
\end{tabular}


Table 12. Estimation results of the regression analysis

\begin{tabular}{lccc}
\hline & Model 1 & Model 2 & Model 3 \\
\hline Distance & $-0.071^{* * *}$ & $-0.066^{* * *}$ & $-0.117^{* * *}$ \\
LCC in comparison to FSNC & & $0.083^{* * *}$ & $0.083^{* * *}$ \\
$\begin{array}{l}\text { Constant term } \\
\text { Year present in model }\end{array}$ & $1.301^{* * *}$ & $1.241^{* * *}$ & $1.508^{* * *}$ \\
$\begin{array}{l}\text { Route Group Index present } \\
\text { in model }\end{array}$ & No & No & Yes \\
\hline $\boldsymbol{N}$ & No & No & Yes \\
$\boldsymbol{R}^{\mathbf{2}}$ & 878 & 878 & 878 \\
$\boldsymbol{r m s e}$ & 0.330 & 0.415 & 0.568 \\
\hline
\end{tabular}

$* \mathrm{p}<0.05, * * \mathrm{p}<0.01, * * * \mathrm{p}<0.001$

Model 1 depicts the influence of flight distance on cabin utilisation. The results show that distance has a negative impact on cabin utilisation. Thus, with increasing distance, cabin utilisation diminishes significantly. This hints towards the fact that with higher travel distance, passenger comfort, in terms of increased seat pitch, improves (Schmidt, 2018) and number of premium seats increases.

In Model 2, the effect of airline business models is added. The regression results show that cabin utilisation significantly increases when an aircraft cluster flight is operated by an LCC, as compared to an FSNC. This suggests that flights by LCCS offer significantly less legroom and passenger comfort. This outcome is in line with the theory on cabin utilisation of LCCS (Kremser, Guenzkofer, Sedlmeier, Sabbah, \& Bengler, 2012).

Finally, we include two control variables (year and route group index) in Model 3 to test whether the coefficients of our variables of interest adhere to the same tendency. As expected, the control variables do not change the impact direction of the variables of interest. Furthermore, the significance of the variables of interest does not change when checking for the control variables. In addition, a better fit of the estimator (suggested by a higher $\mathrm{R}^{2}$ and lower root-mean-square error value) was achieved by testing for the control variables.

A higher cabin utilisation implies more scheduled seats nearing the maximum possible seats per aircraft cluster. This also implies less passenger comfort, for example, when more rows of seats are added to the same aircraft. The results of the regression models therefore suggest that passenger comfort improves with increasing distance and on FSNC flights. Thus, there is a need for more innovative solutions for flexible adjustment of number of installed seats based on demand for short to medium haul flights, especially those operated by LCCs. 


\section{CONCLUSION}

Aircraft cabin configuration is defined in terms of the average scheduled seats, average maximum possible seats, seats per cabin class, and average cabin utilisation of aircraft clusters. Examining the factors to which the configuration of an aircraft cabin is sensitive has been identified as useful in airline operating cost and yield estimation, aircraft conceptual design, and airline fleet planning. Studies have been conducted on the factors influencing aircraft seat capacities. However, none has been conducted analysing aircraft cabin utilisation using data on flights operated by LCCs and FSNCs, averaged within and between global geographical regions and using a clear majority of the global passenger aircraft fleet.

From the study, it is clear that the utilisation of an aircraft's cabin significantly depends on the scheduled flight distance as well as the operating airline's business model. Globally, LCCs had a low preference for premium class seats, especially on their short-haul routes. This study has also given insight into the trend in the average scheduled and maximum possible seats of aircraft, not only globally, but also within and between world regions. The results further suggest that there is no significant difference in aircraft types in the NB aircraft cluster used by LCCS and FSNCs. If this trend continues with the promised middle of market aircraft, a potential market for the aircraft would exist in both business models. By contrast, FSNCs show a greater preference for larger aircraft types in the twin-aisle LR aircraft cluster.

Further research is needed in determining the utilisation of available cargo capacity of aircraft operated on short-haul missions as compared to longer range missions. Also, a more rigorous regression analysis could be performed by using actual, instead of average, flight data and incorporating variables specific to the cities or countries of each specific airport pair. This will enable the investigation of more predictors in greater geographic detail so that more robust conclusions can be drawn.

\section{ACKNOWLEDGEMENTS}

The authors would like to thank Dr. Annika Paul and Anna Straubinger for their constructive comments; as well as Dr. Antoine Habersetzer for his computing assistance. 


\section{Appendix}

Appendix 1: Low-Cost Carriers evaluated in study

\section{Year Low Cost Carriers IATA Codes}

2000 ZA, Z2, YX, XQ, WS, WN, VQ, VA, VA, U2, TZ, TV, TV, SY, SJ, SH, SG, RE, QZ, PE, PC, P9, NK, NJ, NB, N7, LF, KF, JT, JR, JN, IT, IG, HV, HD, GO, G4, FR, FL, FF, F9, DY, DS, DI, DH, DG, DE, C6, BV, BL, BE, BC, B7, B6, AK, 8Q, 6A, 5J, 5D, OB

2004 ZE, ZB, Z4, Z2, YX, Y2, XQ, X3, WW, WS, WO, WN, W6, VY, VQ, VF, VE, VA, VA, UO, U5, U2, TZ, TW, TV, TR, T6, SY, SX, ST, SJ, SH, SG, SG, RE, QZ, QG, PE, PC, PA, OX, O6, NZ, $\mathrm{NK}, \mathrm{NE}, \mathrm{NB}, \mathrm{MN}, \mathrm{LS}, \mathrm{LQ}, \mathrm{LF}, \mathrm{KK}, \mathrm{KI}, \mathrm{KF}, \mathrm{JT}, \mathrm{JR}, \mathrm{JQ}, \mathrm{JN}, \mathrm{IX}, \mathrm{IV}, \mathrm{IT}, \mathrm{IG}, \mathrm{HV}, \mathrm{HQ}, \mathrm{HG}, \mathrm{HD}, \mathrm{HC}$, H2, GX, G9, G4, G3, FR, FL, FD, F9, F7, DY, DS, DJ, DI, DH, DG, DE, DD, C6, C0, BV, BL, $\mathrm{BE}, \mathrm{BC}, \mathrm{B7}, \mathrm{B6}, \mathrm{AK}, 9 \mathrm{X}, 9 \mathrm{C}, 8 \mathrm{Q}, 8 \mathrm{I}, 8 \mathrm{~A}, 7 \mathrm{G}, 6 \mathrm{~A}, 5 \mathrm{P}, 5 \mathrm{~J}, 5 \mathrm{D}, 4 \mathrm{U}, 4 \mathrm{P}, 3 \mathrm{~L}, 3 \mathrm{~K}, 3 \mathrm{~J}, 2 \mathrm{~L}, 0 \mathrm{~B}$

2008 ZS, ZG, ZE, ZB, Z4, Z2, YX, YV, Y4, Y2, XY, XW, XQ, XG, X3, WW, WU, WS, WO, WN, WH, WG, W6, VY, VX, VF, VE, VB, VA, V5, UO, U5, U2, TZ, TW, TT, TR, TO, T6, SY, SX, SJ, SG, $\mathrm{RE}, \mathrm{QZ}, \mathrm{QS}, \mathrm{QG}, \mathrm{QA}, \mathrm{PE}, \mathrm{PC}, \mathrm{PA}, \mathrm{O8}, \mathrm{O6}, \mathrm{NZ}, \mathrm{NM}, \mathrm{NK}, \mathrm{NE}, \mathrm{NB}, \mathrm{MN}, \mathrm{MJ}, \mathrm{LZ}, \mathrm{LS}, \mathrm{LQ}, \mathrm{L}, \mathrm{LF}$, $\mathrm{KK}, \mathrm{KI}, \mathrm{KF}, \mathrm{JT}$, JR, JQ, JN, JE, J9, IX, IV, IT, IG, HV, HG, HD, HC, H2, G9, G8, G4, G3, FZ, $\mathrm{FR}, \mathrm{FL}, \mathrm{FD}, \mathrm{F9}, \mathrm{F7}$, DY, DS, DJ, DG, DE, DD, D7, C6, C4, C0, BV, BL, BE, BC, B6, AK, AD, 9X, 9C, 8Z, 8Q, 8J, 8I, 8A, 7H, 7G, 7C, 6E, 6A, 5P, 5K, 5J, 4U, 4O, 3L, 3K, 2P, 2L, 0B

2012 ZE, ZB, Z2, YV, Y4, XY, XQ, X3, WW, WU, WS, WN, WH, WG, W6, VY, VX, VJ, VF, VE, VB, VA, V7, UO, U5, U2, TW, TT, TR, TO, T6, SY, SG, RI, RE, QZ, QS, QG, PQ, PC, PA, OD, NZ, NM, NK, MN, MM, MJ, LZ, LS, LQ, L, KK, KF, JW, JT, JQ, JE, J9, IX, IV, IG, HV, HG, HD, $H C, H 2, G K, G 9, G 8, G 4, G 3, F Z, F R$, FN, FL, FD, FC, F9, E5, DY, DS, DJ, DG, DE, DD, DC, $\mathrm{D} 7, \mathrm{C6}, \mathrm{BV}, \mathrm{BL}, \mathrm{BE}, \mathrm{BC}, \mathrm{B6}, \mathrm{AK}, \mathrm{AD}, 9 \mathrm{C}, 8 \mathrm{Q}, 8 \mathrm{~J}, 7 \mathrm{H}, 7 \mathrm{G}, 7 \mathrm{C}, 6 \mathrm{E}, 5 \mathrm{P}, 5 \mathrm{~K}, 5 \mathrm{~J}, 4 \mathrm{U}, 4 \mathrm{O}, 3 \mathrm{O}, 3 \mathrm{~L}$, $3 \mathrm{~K}, 2 \mathrm{P}, 2 \mathrm{~L}, \mathrm{OB}$

2014 ZE, ZB, Z2, YV, Y5, Y4, XY, XQ, X3, WW, WU, WS, WN, WG, W6, VY, VX, VJ, VF, VE, VB, VA, V7, UO, U2, TW, TT, TR, TO, SY, SL, SG, RI, RE, QZ, QS, QG, PQ, PC, PA, OD, NZ, NK, MN, MM, MJ, LS, LQ, L, KK, KF, JX, JW, JT, JQ, JE, J9, IX, IG, HV, HG, HD, H2, GK, G9, G8, G4, G3, FZ, FR, FN, FL, FD, FC, F9, E5, DY, DS, DJ, DG, DE, DD, DC, D7, C6, BV, BL, $\mathrm{BE}, \mathrm{BC}, \mathrm{B6}, \mathrm{AK}, \mathrm{AD}, 9 \mathrm{C}, 8 \mathrm{Q}, 7 \mathrm{H}, 7 \mathrm{G}, 7 \mathrm{C}, 6 \mathrm{E}, 5 \mathrm{P}, 5 \mathrm{~K}, 5 \mathrm{~J}, 4 \mathrm{U}, 4 \mathrm{O}, 3 \mathrm{O}, 3 \mathrm{~L}, 3 \mathrm{~K}, 2 \mathrm{P}, 2 \mathrm{~L}, 0 \mathrm{~B}$ 2016 E5, JX, 30, MN, JE, FN, JQ, TT, VA, 9C, UO, IX, G8, 6E, SG, QG, QZ, JT, RI, HD, GK, MM, BC, LQ, 7G, JW, AK, D7, OD, Y5, NZ, PA, Z2, 5J, 2P, PQ, DG, DJ, 3K, TR, VF, ZE, 7C, LJ, TW, MJ, DD, FD, SL, BL, VJ, 3L, HG, QS, KF, TO, DE, 4U, X3, 5P, W6, WW, RE, FR, BV, IG, HV, DY, 5K, OB, V7, VY, DC, DS, 2L, KK, 7H, 8Q, PC, XQ, WU, U2, BE, LS, ZB, AD, G3, H2, VE, FC, 40, VB, Y4, J9, XY, G9, FZ, C6, WG, WS, FL, G4, F9, YV, B6, WN, NK, SY, VX, BF, RS, TZ, V6, 2D, 5F, 6F, 6J, 7B, 8W, AJA, AQ, CO, D8, DP, E2, RN, RY, TRJ, VNE, VU, VZ, $X W, 2 B, 9 P, F T, G M, G Y, O R$

Appendix 2: Historical Development of Aircraft Cluster Average Seat Capacity, all airlines

\begin{tabular}{ccccccccc}
\hline A/C & $\mathbf{2 0 0 0}$ & $\mathbf{2 0 0 4}$ & $\mathbf{2 0 0 8}$ & $\mathbf{2 0 1 2}$ & $\mathbf{2 0 1 4}$ & $\mathbf{2 0 1 6}$ & $\begin{array}{c}\text { Average } \\
\text { Annual Growth } \\
\text { Rate 2000- } \\
\mathbf{2 0 1 6} \\
\text { [\% p.a.] }\end{array}$ & $\begin{array}{c}\text { Average } \\
\text { Annual Growth } \\
\text { Rate 2008- } \\
\text { 2016 } \\
\text { [\% p.a.] }\end{array}$ \\
\hline LRC & 273 & 277 & 261 & 255 & 326 & 291 & 0.7 & 1.5 \\
LRH & 389 & 383 & 372 & 366 & 347 & 374 & -0.2 & 0.0 \\
JC & 66 & 61 & 65 & 68 & 70 & 72 & 0.6 & 1.4 \\
TC & 67 & 68 & 68 & 69 & 68 & 69 & 0.2 & 0.1 \\
MR & 207 & 217 & 219 & 227 & 237 & 250 & 1.2 & 1.5 \\
LR & 288 & 282 & 284 & 287 & 294 & 302 & 0.3 & 0.7 \\
NB & 135 & 139 & 146 & 153 & 158 & 162 & 1.1 & 1.3 \\
\hline
\end{tabular}


Appendix 3: Historical Development of Aircraft Cluster Average Seat Capacity, FSNC

\begin{tabular}{ccccccccc}
\hline A/C & $\mathbf{2 0 0 0}$ & $\mathbf{2 0 0 4}$ & $\mathbf{2 0 0 8}$ & $\mathbf{2 0 1 2}$ & $\mathbf{2 0 1 4}$ & $\mathbf{2 0 1 6}$ & $\begin{array}{c}\text { Average Annual } \\
\text { Growth Rate } \\
\mathbf{2 0 0 0 - 2 0 1 6}[\%]\end{array}$ & $\begin{array}{c}\text { Average Annual } \\
\text { Growth Rate } \\
\mathbf{2 0 0 8 - 2 0 1 6}[\%]\end{array}$ \\
\hline LRC & 273 & 277 & 261 & 255 & 326 & 291 & 0.7 & 1.5 \\
LRH & 389 & 382 & 372 & 366 & 347 & 374 & -0.2 & 0.1 \\
JC & 66 & 61 & 64 & 66 & 68 & 71 & 0.5 & 1.3 \\
TC & 67 & 68 & 68 & 69 & 68 & 69 & 0.2 & 0.1 \\
MR & 207 & 217 & 219 & 227 & 235 & 247 & 1.1 & 1.4 \\
LR & 288 & 282 & 284 & 287 & 294 & 301 & 0.3 & 0.7 \\
NB & 136 & 138 & 143 & 149 & 152 & 156 & 0.9 & 1.1 \\
\hline
\end{tabular}

Appendix 4: Historical Development of Aircraft Cluster Average Seat Capacity, LCC

\begin{tabular}{ccccccccc}
\hline A/C & $\mathbf{2 0 0 0}$ & $\mathbf{2 0 0 4}$ & $\mathbf{2 0 0 8}$ & $\mathbf{2 0 1 2}$ & $\mathbf{2 0 1 4}$ & $\mathbf{2 0 1 6}$ & $\begin{array}{c}\text { Average Annual } \\
\text { Growth Rate } \\
\text { 2000-2016[\%] }\end{array}$ & $\begin{array}{c}\text { Average Annual } \\
\text { Growth Rate } \\
\text { 2008-2016 [\%] }\end{array}$ \\
\hline LRC & 290 & & & & & & & \\
LRH & 480 & 407 & 376 & 360 & 346 & 336 & -2.1 & -1.4 \\
JC & 115 & 69 & 84 & 98 & 99 & 100 & 0.0 & 2.7 \\
TC & & 67 & 67 & 70 & 69 & 69 & 0.2 & 0.3 \\
MR & 205 & 226 & 246 & 253 & 294 & 309 & 2.7 & 2.9 \\
LR & 318 & 267 & 308 & 297 & 302 & 321 & 0.2 & 0.9 \\
NB & 135 & 143 & 151 & 160 & 168 & 171 & 1.5 & 1.6 \\
\hline
\end{tabular}

Appendix 5: Historical Development of Aircraft Cabin utilisation for all Airlines on Intra- and Inter-Regional Flights

\begin{tabular}{lllllllll}
\hline Route Group & A/C & $\mathbf{2 0 0}$ & $\mathbf{2 0 0}$ & $\mathbf{2 0 0}$ & $\mathbf{2 0 1}$ & $\mathbf{2 0 1}$ & $\mathbf{2 0 1 6}$ \\
\hline \multirow{2}{*}{ Intra North } & JC & $73 \%$ & $70 \%$ & $74 \%$ & $77 \%$ & $78 \%$ & $79 \%$ \\
America & NB & $83 \%$ & $83 \%$ & $85 \%$ & $87 \%$ & $88 \%$ & $89 \%$ \\
& LR & $65 \%$ & $67 \%$ & $71 \%$ & $64 \%$ & $73 \%$ & $72 \%$ \\
Intra Europe & JC & $81 \%$ & $85 \%$ & $89 \%$ & $92 \%$ & $93 \%$ & $93 \%$ \\
& NB & $79 \%$ & $84 \%$ & $89 \%$ & $90 \%$ & $92 \%$ & $94 \%$ \\
Intra-Asia & LR & $60 \%$ & $66 \%$ & $65 \%$ & $71 \%$ & $72 \%$ & $73 \%$ \\
& JC & $96 \%$ & $81 \%$ & $82 \%$ & $86 \%$ & $87 \%$ & $91 \%$ \\
North America- & NB & $83 \%$ & $84 \%$ & $86 \%$ & $86 \%$ & $88 \%$ & $89 \%$ \\
Europe & LR & $74 \%$ & $72 \%$ & $68 \%$ & $71 \%$ & $71 \%$ & $72 \%$ \\
& JC & & & $82 \%$ & $24 \%$ & $29 \%$ & $24 \%$ \\
Europe-Asia & NB & $88 \%$ & $66 \%$ & $54 \%$ & $68 \%$ & $85 \%$ & $83 \%$ \\
& LR & $61 \%$ & $60 \%$ & $64 \%$ & $63 \%$ & $65 \%$ & $67 \%$ \\
Asia-North & N & $89 \%$ & $92 \%$ & $94 \%$ & $91 \%$ & $89 \%$ & $86 \%$ \\
America & NB & $80 \%$ & $81 \%$ & $81 \%$ & $84 \%$ & $84 \%$ & $87 \%$ \\
& LR & $62 \%$ & $66 \%$ & $66 \%$ & $64 \%$ & $64 \%$ & $67 \%$ \\
\hline
\end{tabular}


Appendix 6: Historical Development of Aircraft Cabin utilisation for all FSNCs and LCCs on Intra-Regional Flights

\begin{tabular}{|c|c|c|c|c|c|c|c|c|}
\hline & & & 2000 & 2004 & 2008 & 2012 & 2014 & 2016 \\
\hline \multirow{9}{*}{ FSNC } & \multirow{3}{*}{$\begin{array}{c}\text { Intra North } \\
\text { America }\end{array}$} & $\mathrm{JC}$ & $73 \%$ & $70 \%$ & $73 \%$ & $76 \%$ & $78 \%$ & $78 \%$ \\
\hline & & NB & $82 \%$ & $80 \%$ & $81 \%$ & $82 \%$ & $84 \%$ & $86 \%$ \\
\hline & & LR & $65 \%$ & $67 \%$ & $71 \%$ & $64 \%$ & $73 \%$ & $72 \%$ \\
\hline & \multirow{4}{*}{$\begin{array}{l}\text { Intra } \\
\text { Europe }\end{array}$} & JC & $81 \%$ & $84 \%$ & $89 \%$ & $92 \%$ & $92 \%$ & $93 \%$ \\
\hline & & NB & $79 \%$ & $81 \%$ & $84 \%$ & $84 \%$ & $88 \%$ & $89 \%$ \\
\hline & & LR & $60 \%$ & $66 \%$ & $65 \%$ & $71 \%$ & $71 \%$ & $73 \%$ \\
\hline & & JC & $96 \%$ & $81 \%$ & $78 \%$ & $86 \%$ & $87 \%$ & $91 \%$ \\
\hline & \multirow[t]{2}{*}{ Intra-Asia } & NB & $83 \%$ & $84 \%$ & $84 \%$ & $83 \%$ & $84 \%$ & $85 \%$ \\
\hline & & LR & $74 \%$ & $72 \%$ & $68 \%$ & $71 \%$ & $71 \%$ & $72 \%$ \\
\hline \multirow{9}{*}{ LCC } & \multirow{3}{*}{$\begin{array}{c}\text { Intra North } \\
\text { America }\end{array}$} & JC & $92 \%$ & $66 \%$ & $79 \%$ & $86 \%$ & $88 \%$ & $88 \%$ \\
\hline & & NB & $89 \%$ & $90 \%$ & $91 \%$ & $92 \%$ & $93 \%$ & $93 \%$ \\
\hline & & LR & & & & & & \\
\hline & \multirow{4}{*}{$\begin{array}{l}\text { Intra } \\
\text { Europe }\end{array}$} & JC & $89 \%$ & $86 \%$ & $93 \%$ & $88 \%$ & $96 \%$ & $99 \%$ \\
\hline & & NB & $86 \%$ & $93 \%$ & $98 \%$ & $98 \%$ & $99 \%$ & $99 \%$ \\
\hline & & LR & $67 \%$ & $70 \%$ & & & $94 \%$ & $71 \%$ \\
\hline & & JC & & $88 \%$ & $96 \%$ & & & $88 \%$ \\
\hline & \multirow[t]{2}{*}{ Intra-Asia } & NB & $89 \%$ & $90 \%$ & $93 \%$ & $95 \%$ & $99 \%$ & $99 \%$ \\
\hline & & LR & & $70 \%$ & $76 \%$ & $73 \%$ & $65 \%$ & $91 \%$ \\
\hline
\end{tabular}

Appendix 7: Historical Development of Aircraft Cabin utilisation for all FSNCs and LCCs on Inter-Regional Flights

\begin{tabular}{|c|c|c|c|c|c|c|c|c|}
\hline & & & 2000 & 2004 & 2008 & 2012 & 2014 & 2016 \\
\hline \multirow{3}{*}{ FSNC } & $\begin{array}{l}\text { North America- } \\
\text { Europe }\end{array}$ & LR & $61 \%$ & $60 \%$ & $64 \%$ & $63 \%$ & $65 \%$ & $67 \%$ \\
\hline & Europe-Asia & LR & $62 \%$ & $66 \%$ & $66 \%$ & $64 \%$ & $64 \%$ & $67 \%$ \\
\hline & Asia-North America & LR & $60 \%$ & $64 \%$ & $65 \%$ & $63 \%$ & $62 \%$ & $66 \%$ \\
\hline \multirow{3}{*}{ LCC } & $\begin{array}{l}\text { North America- } \\
\text { Europe }\end{array}$ & LR & & & $71 \%$ & $69 \%$ & $73 \%$ & $73 \%$ \\
\hline & Europe-Asia & LR & & $70 \%$ & & $65 \%$ & $58 \%$ & $80 \%$ \\
\hline & Asia-North America & LR & & & & & & $89 \%$ \\
\hline
\end{tabular}


Appendix 8: Historical Development of Aircraft Seat Capacities for all Airlines on Intra-Regional Flights

\begin{tabular}{|c|c|c|c|c|c|c|c|}
\hline & & 2000 & 2004 & 2008 & 2012 & 2014 & 2016 \\
\hline \multirow{6}{*}{$\begin{array}{l}\text { Intra North } \\
\text { America }\end{array}$} & LRC & 272 & 272 & 42 & & & \\
\hline & LRH & 371 & 344 & 383 & 68 & 80 & 374 \\
\hline & $\mathrm{JC}$ & 58 & 54 & 58 & 60 & 61 & 64 \\
\hline & $\mathrm{TC}$ & 65 & 66 & 65 & 72 & 72 & 72 \\
\hline & MR & 186 & 196 & 193 & 188 & 191 & 199 \\
\hline & LR & 286 & 276 & 298 & 260 & 297 & 299 \\
\hline \multirow{9}{*}{ Intra Europe } & NB & 132 & 133 & 135 & 141 & 146 & 151 \\
\hline & LRC & 281 & 275 & 0 & & 409 & \\
\hline & LRH & 380 & 391 & 378 & 365 & 389 & 406 \\
\hline & $\mathrm{JC}$ & 73 & 74 & 76 & 83 & 88 & 91 \\
\hline & TC & 67 & 69 & 69 & 69 & 65 & 69 \\
\hline & MR & 208 & 215 & 217 & 220 & 233 & 238 \\
\hline & LR & 252 & 274 & 277 & 284 & 290 & 295 \\
\hline & NB & 139 & 146 & 153 & 159 & 165 & 169 \\
\hline & LRC & & & & 270 & 446 & 450 \\
\hline \multirow{6}{*}{$\begin{array}{l}\text { Intra Middle } \\
\text { East }\end{array}$} & LRH & 390 & 383 & 381 & 375 & 385 & 388 \\
\hline & $\mathrm{JC}$ & 101 & 103 & 87 & 86 & 85 & 83 \\
\hline & $\mathrm{TC}$ & 72 & 71 & 68 & 67 & 65 & 66 \\
\hline & MR & 211 & 232 & 222 & 241 & 260 & 266 \\
\hline & LR & 266 & 260 & 261 & 273 & 289 & 307 \\
\hline & NB & 130 & 136 & 143 & 153 & 149 & 151 \\
\hline \multirow{7}{*}{ Intra Africa } & LRC & 272 & 256 & 285 & 95 & & \\
\hline & LRH & 375 & 369 & 372 & 390 & 416 & 368 \\
\hline & $\mathrm{JC}$ & 67 & 90 & 82 & 69 & 74 & 72 \\
\hline & $\mathrm{TC}$ & 69 & 70 & 69 & 62 & 69 & 69 \\
\hline & MR & 211 & 225 & 220 & 237 & 236 & 243 \\
\hline & LR & 259 & 266 & 270 & 279 & 278 & 285 \\
\hline & NB & 128 & 133 & 139 & 141 & 144 & 148 \\
\hline \multirow{7}{*}{$\begin{array}{l}\text { Intra Latin } \\
\text { America }\end{array}$} & LRC & 282 & 281 & 294 & 204 & & \\
\hline & LRH & 412 & 387 & 339 & 394 & 375 & 405 \\
\hline & $\mathrm{JC}$ & 88 & 87 & 78 & 80 & 87 & 86 \\
\hline & $\mathrm{TC}$ & 65 & 65 & 65 & 70 & 69 & 69 \\
\hline & MR & 197 & 205 & 201 & 204 & 213 & 226 \\
\hline & LR & 263 & 258 & 259 & 260 & 285 & 296 \\
\hline & NB & 129 & 135 & 142 & 152 & 156 & 158 \\
\hline \multirow{7}{*}{ Intra Asia } & LRC & 274 & 276 & 260 & 274 & 272 & 265 \\
\hline & LRH & 388 & 379 & 368 & 371 & 360 & 383 \\
\hline & $\mathrm{JC}$ & 92 & 74 & 71 & 75 & 69 & 79 \\
\hline & $\mathrm{TC}$ & 70 & 70 & 70 & 70 & 70 & 70 \\
\hline & MR & 238 & 240 & 245 & 255 & 267 & 276 \\
\hline & LR & 330 & 317 & 295 & 304 & 307 & 308 \\
\hline & NB & 145 & 145 & 150 & 156 & 161 & 165 \\
\hline
\end{tabular}


Appendix 9: Historical Development of Aircraft Seat Capacities for all Airlines on Inter-Regional Flights

\begin{tabular}{|c|c|c|c|c|c|c|c|}
\hline Route Group & $A / C$ & 2000 & 2004 & 2008 & 2012 & 2014 & 2016 \\
\hline \multirow{7}{*}{$\begin{array}{l}\text { North America- } \\
\text { Europe }\end{array}$} & LRC & 264 & 278 & 243 & 273 & 280 & 274 \\
\hline & LRH & 403 & 394 & 351 & 371 & 350 & 348 \\
\hline & $\mathrm{JC}$ & & & 66 & 32 & 38 & 32 \\
\hline & TC & & & & & & \\
\hline & MR & 213 & 220 & 221 & 229 & 230 & 233 \\
\hline & LR & 265 & 263 & 275 & 269 & 275 & 284 \\
\hline & NB & 147 & 108 & 93 & 127 & 131 & 155 \\
\hline \multirow{7}{*}{ Europe-Asia } & LRC & 269 & 277 & 257 & 273 & 305 & 274 \\
\hline & LRH & 391 & 382 & 372 & 373 & 339 & 385 \\
\hline & $\mathrm{JC}$ & 75 & 70 & 75 & 60 & 61 & 62 \\
\hline & TC & & & 72 & 69 & 71 & 70 \\
\hline & MR & 214 & 209 & 213 & 244 & 256 & 261 \\
\hline & LR & 265 & 282 & 287 & 281 & 279 & 292 \\
\hline & NB & 144 & 144 & 139 & 145 & 149 & 158 \\
\hline \multirow{6}{*}{$\begin{array}{l}\text { Asia-North } \\
\text { America }\end{array}$} & LRC & 278 & 270 & 288 & 270 & 264 & 264 \\
\hline & LRH & 382 & 372 & 382 & 338 & 296 & 354 \\
\hline & $\mathrm{JC}$ & & & 0 & & & \\
\hline & TC & & & & 72 & & \\
\hline & MR & 198 & 214 & 242 & 231 & 243 & 249 \\
\hline & LR & 266 & 282 & 287 & 276 & 275 & 290 \\
\hline \multirow{8}{*}{$\begin{array}{l}\text { North America- } \\
\text { Latin America }\end{array}$} & NB & 164 & 164 & 151 & 120 & 108 & 157 \\
\hline & LRC & 252 & 281 & & 0 & 0 & 0 \\
\hline & LRH & 367 & 355 & 384 & 342 & 357 & 371 \\
\hline & $\mathrm{JC}$ & 44 & 43 & 54 & 63 & 63 & 71 \\
\hline & TC & 64 & 64 & 64 & 72 & & \\
\hline & MR & 190 & 207 & 204 & 197 & 199 & 204 \\
\hline & LR & 266 & 240 & 254 & 248 & 260 & 275 \\
\hline & NB & 140 & 139 & 143 & 146 & 150 & 156 \\
\hline \multirow{7}{*}{$\begin{array}{l}\text { North America- } \\
\text { Middle East }\end{array}$} & LRC & 371 & & & & & \\
\hline & LRH & 430 & 438 & 433 & 373 & 363 & 401 \\
\hline & $\mathrm{JC}$ & & & & 109 & & \\
\hline & TC & & & & & & \\
\hline & MR & 213 & 212 & 213 & 238 & 236 & 222 \\
\hline & LR & 283 & 284 & 308 & 302 & 309 & 323 \\
\hline & NB & 144 & & & & & 165 \\
\hline \multirow{7}{*}{$\begin{array}{c}\text { North America- } \\
\text { Africa }\end{array}$} & LRC & & & & & & \\
\hline & LRH & 366 & 362 & 447 & 358 & 359 & 369 \\
\hline & $\mathrm{JC}$ & & & & & & \\
\hline & TC & & & & & & \\
\hline & MR & 225 & 236 & 223 & 224 & 231 & 237 \\
\hline & LR & 319 & 304 & 291 & 271 & 280 & 293 \\
\hline & NB & & & & & & 120 \\
\hline \multirow{7}{*}{ Europe- Africa } & LRC & 274 & 269 & 282 & 150 & 6 & 16 \\
\hline & LRH & 381 & 389 & 345 & 407 & 391 & 363 \\
\hline & $\mathrm{JC}$ & 84 & 109 & 104 & 99 & 104 & 97 \\
\hline & TC & 70 & 72 & 72 & 69 & 70 & 70 \\
\hline & MR & 219 & 236 & 237 & 255 & 248 & 262 \\
\hline & LR & 262 & 265 & 278 & 278 & 282 & 284 \\
\hline & NB & 144 & 149 & 153 & 159 & 161 & 162 \\
\hline \multirow{7}{*}{$\begin{array}{l}\text { Latin America- } \\
\text { Europe }\end{array}$} & LRC & 283 & 278 & 268 & 287 & 303 & 274 \\
\hline & LRH & 422 & 409 & 400 & 410 & 398 & 406 \\
\hline & $\mathrm{JC}$ & & & & 100 & & \\
\hline & TC & & & & & & \\
\hline & MR & 227 & 235 & 247 & 246 & 275 & 288 \\
\hline & LR & 258 & 272 & 281 & 285 & 306 & 309 \\
\hline & NB & 150 & 132 & 122 & 149 & 156 & 159 \\
\hline \multirow{2}{*}{$\begin{array}{c}\text { Africa-Middle } \\
\text { East }\end{array}$} & LRC & & & & 240 & 444 & 450 \\
\hline & LRH & 377 & 371 & 376 & 369 & 375 & 363 \\
\hline
\end{tabular}




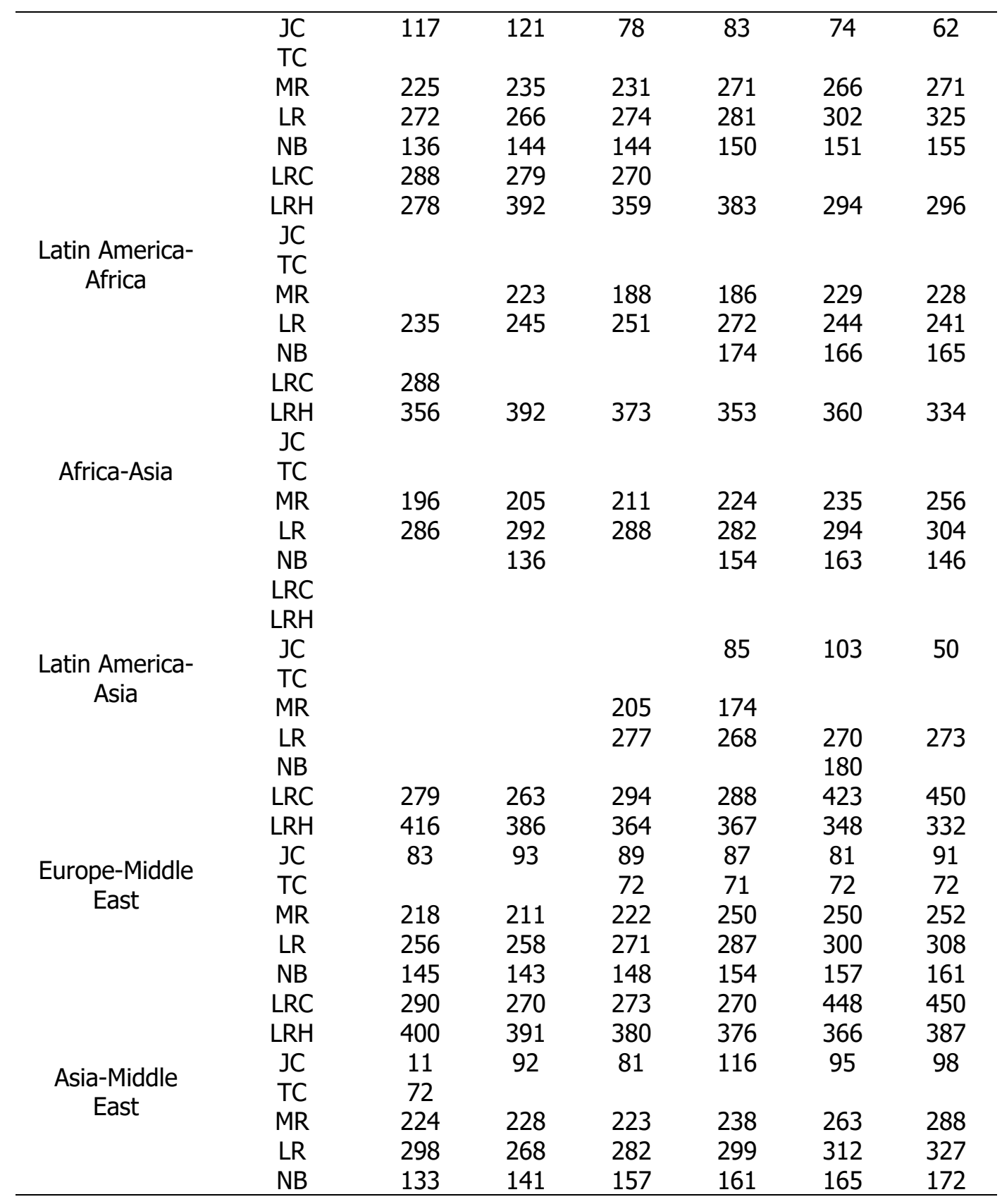


Appendix 10: Historical Development of Aircraft Seat Capacities for FSNC IntraRegional Flights

\begin{tabular}{|c|c|c|c|c|c|c|c|}
\hline $\begin{array}{l}\text { Route } \\
\text { Group }\end{array}$ & $A / C$ & 2000 & 2004 & 2008 & 2012 & 2014 & 2016 \\
\hline \multirow{7}{*}{$\begin{array}{l}\text { Intra North } \\
\text { America }\end{array}$} & LRC & 272.4 & 271.8 & 42.2 & & & \\
\hline & LRH & 362.9 & 344.4 & 382.9 & 67.6 & 80.4 & 373.6 \\
\hline & $\mathrm{JC}$ & 57.2 & 53.5 & 56.6 & 58.5 & 59.7 & 61.8 \\
\hline & $\mathrm{TC}$ & 65.0 & 65.6 & 65.2 & 72.0 & 72.0 & 71.5 \\
\hline & MR & 185.8 & 195.0 & 192.4 & 188.4 & 190.9 & 199.4 \\
\hline & LR & 285.8 & 275.6 & 297.6 & 260.5 & 297.0 & 298.7 \\
\hline & NB & 131.7 & 131.5 & 135.6 & 143.5 & 147.0 & 150.4 \\
\hline \multirow{7}{*}{$\begin{array}{l}\text { Intra } \\
\text { Europe }\end{array}$} & LRC & 281.2 & 274.8 & 0.0 & & 409.1 & \\
\hline & LRH & 379.8 & 390.9 & 377.9 & 365.2 & 389.0 & 406.2 \\
\hline & $\mathrm{JC}$ & 73.4 & 72.9 & 76.3 & 82.4 & 88.2 & 91.2 \\
\hline & $\mathrm{TC}$ & 66.9 & 68.9 & 69.3 & 68.3 & 64.2 & 69.1 \\
\hline & MR & 209.9 & 211.6 & 210.1 & 219.2 & 227.8 & 231.3 \\
\hline & LR & 251.7 & 273.9 & 277.2 & 283.6 & 288.9 & 295.8 \\
\hline & NB & 138.4 & 142.0 & 145.2 & 150.2 & 156.1 & 161.0 \\
\hline \multirow{7}{*}{$\begin{array}{l}\text { Intra } \\
\text { Middle East }\end{array}$} & LRC & & & & 270.0 & 445.6 & 450.0 \\
\hline & LRH & 390.0 & 383.0 & 380.9 & 373.9 & 385.5 & 387.7 \\
\hline & $\mathrm{JC}$ & 101.3 & 103.0 & 87.0 & 85.6 & 85.0 & 83.0 \\
\hline & $\mathrm{TC}$ & 72.0 & 71.0 & 68.0 & 67.3 & 64.7 & 66.4 \\
\hline & MR & 210.7 & 231.9 & 222.2 & 241.2 & 259.6 & 266.0 \\
\hline & LR & 265.6 & 259.6 & 261.4 & 273.1 & 288.9 & 307.2 \\
\hline & NB & 129.6 & 135.8 & 141.8 & 148.3 & 142.9 & 144.7 \\
\hline \multirow{7}{*}{ Intra Africa } & LRC & 272.2 & 256.2 & 285.0 & 95.0 & & \\
\hline & LRH & 375.3 & 368.7 & 371.9 & 390.0 & 416.0 & 368.4 \\
\hline & $\mathrm{JC}$ & 66.6 & 90.8 & 81.5 & 68.8 & 73.6 & 72.9 \\
\hline & $\mathrm{TC}$ & 68.8 & 69.8 & 69.2 & 62.5 & 68.9 & 69.0 \\
\hline & MR & 211.1 & 224.9 & 219.3 & 237.6 & 235.3 & 243.2 \\
\hline & LR & 259.1 & 265.8 & 270.4 & 279.1 & 277.7 & 285.3 \\
\hline & NB & 127.6 & 132.1 & 136.7 & 137.8 & 139.3 & 142.7 \\
\hline \multirow{7}{*}{$\begin{array}{l}\text { Intra Latin } \\
\text { America }\end{array}$} & LRC & 282.3 & 281.2 & 294.0 & 203.8 & & \\
\hline & LRH & 412.3 & 386.9 & 339.1 & 394.4 & 374.8 & 405.3 \\
\hline & $\mathrm{JC}$ & 88.0 & 86.7 & 81.5 & 77.9 & 83.8 & 83.0 \\
\hline & $\mathrm{TC}$ & 64.8 & 64.9 & 65.2 & 69.3 & 70.3 & 68.7 \\
\hline & MR & 196.5 & 204.3 & 199.9 & 204.1 & 211.1 & 224.2 \\
\hline & $\mathrm{LR}$ & 261.7 & 258.2 & 259.4 & 259.8 & 285.5 & 297.5 \\
\hline & NB & 129.6 & 134.7 & 140.8 & 149.3 & 152.0 & 154.2 \\
\hline \multirow{7}{*}{ Intra Asia } & LRC & 273.6 & 275.8 & 260.1 & 274.0 & 272.2 & 264.5 \\
\hline & LRH & 387.5 & 377.9 & 368.4 & 371.0 & 359.6 & 383.1 \\
\hline & $\mathrm{JC}$ & 92.0 & 73.6 & 61.4 & 75.3 & 69.2 & 79.0 \\
\hline & $\mathrm{TC}$ & 70.0 & 69.9 & 69.7 & 70.3 & 69.2 & 69.5 \\
\hline & MR & 237.2 & 240.8 & 245.5 & 253.6 & 263.6 & 272.5 \\
\hline & LR & 330.4 & 316.7 & 295.0 & 304.3 & 306.7 & 306.2 \\
\hline & NB & 144.7 & 145.1 & 147.4 & 150.7 & 154.5 & 159.0 \\
\hline
\end{tabular}


Appendix 11: Historical Development of Aircraft Seat Capacities for FSNC InterRegional Flights

\begin{tabular}{|c|c|c|c|c|c|c|c|}
\hline Route Group & A/C & 2000 & 2004 & 2008 & 2012 & 2014 & 2016 \\
\hline \multirow{7}{*}{$\begin{array}{l}\text { North America- } \\
\text { Europe }\end{array}$} & LRC & 264 & 278 & 243 & 273 & 280 & 274 \\
\hline & LRH & 403 & 394 & 351 & 371 & 351 & 348 \\
\hline & $\mathrm{JC}$ & & & 66 & 32 & 38 & 32 \\
\hline & $\mathrm{TC}$ & & & & & & \\
\hline & MR & 213 & 220 & 221 & 229 & 230 & 232 \\
\hline & LR & 265 & 263 & 275 & 269 & 275 & 284 \\
\hline & NB & 147 & 108 & 93 & 127 & 129 & 116 \\
\hline \multirow{7}{*}{ Europe-Asia } & LRC & 269 & 277 & 257 & 273 & 305 & 274 \\
\hline & LRH & 391 & 382 & 372 & 373 & 339 & 385 \\
\hline & $\mathrm{JC}$ & 75 & 70 & 75 & 60 & 61 & 62 \\
\hline & TC & & & 72 & 69 & 71 & 70 \\
\hline & MR & 212 & 207 & 212 & 243 & 256 & 261 \\
\hline & LR & 265 & 282 & 287 & 281 & 280 & 292 \\
\hline & NB & 144 & 144 & 140 & 145 & 149 & 157 \\
\hline \multirow{7}{*}{$\begin{array}{l}\text { Asia-North } \\
\text { America }\end{array}$} & LRC & 278 & 270 & 288 & 270 & 264 & 264 \\
\hline & LRH & 382 & 372 & 382 & 338 & 296 & 354 \\
\hline & $\mathrm{JC}$ & & & 0 & & & \\
\hline & TC & & & & 72 & & \\
\hline & MR & 198 & 214 & 242 & 231 & 243 & 249 \\
\hline & LR & 266 & 282 & 287 & 276 & 275 & 289 \\
\hline & NB & 164 & 164 & 151 & 120 & 108 & 157 \\
\hline \multirow{7}{*}{$\begin{array}{l}\text { North America- } \\
\text { Latin America }\end{array}$} & LRC & 252 & 281 & & 0 & 0 & 0 \\
\hline & LRH & 352 & 355 & 384 & 342 & 357 & 371 \\
\hline & $\mathrm{JC}$ & 44 & 43 & 52 & 55 & 57 & 66 \\
\hline & TC & 64 & 64 & 64 & 72 & & \\
\hline & MR & 190 & 207 & 204 & 197 & 199 & 203 \\
\hline & LR & 266 & 240 & 254 & 248 & 260 & 276 \\
\hline & NB & 142 & 139 & 142 & 144 & 148 & 153 \\
\hline \multirow{6}{*}{$\begin{array}{l}\text { North America- } \\
\text { Middle East }\end{array}$} & LRC & 371 & & & & & \\
\hline & LRH & 424 & 438 & 433 & 373 & 363 & 401 \\
\hline & $\mathrm{JC}$ & & & & 109 & & \\
\hline & TC & & & & & & \\
\hline & MR & 213 & 212 & 213 & 238 & 236 & 222 \\
\hline & LR & 283 & 284 & 308 & 302 & 309 & 323 \\
\hline \multirow{7}{*}{$\begin{array}{l}\text { North America- } \\
\text { Africa }\end{array}$} & INB & 144 & & & & & 165 \\
\hline & LRH & 366 & 362 & 447 & 358 & 359 & 369 \\
\hline & $\mathrm{JC}$ & & & & & & \\
\hline & TC & & & & & & \\
\hline & MR & 225 & 236 & 223 & 224 & 231 & 237 \\
\hline & LR & 319 & 304 & 291 & 271 & 280 & 293 \\
\hline & NB & & & & & & 120 \\
\hline \multirow{7}{*}{ Europe- Africa } & LRC & 274 & 269 & 282 & 150 & 6 & 16 \\
\hline & LRH & 381 & 389 & 345 & 407 & 391 & 363 \\
\hline & $\mathrm{JC}$ & 84 & 109 & 104 & 99 & 104 & 97 \\
\hline & TC & 70 & 72 & 72 & 69 & 70 & 70 \\
\hline & MR & 219 & 236 & 235 & 256 & 246 & 262 \\
\hline & LR & 262 & 265 & 278 & 278 & 282 & 284 \\
\hline & NB & 144 & 148 & 149 & 155 & 155 & 156 \\
\hline \multirow{7}{*}{$\begin{array}{l}\text { Latin America- } \\
\text { Europe }\end{array}$} & LRC & 283 & 278 & 268 & 287 & 303 & 274 \\
\hline & LRH & 422 & 409 & 400 & 410 & 398 & 406 \\
\hline & $\mathrm{JC}$ & & & & 100 & & \\
\hline & TC & & & & & & \\
\hline & MR & 220 & 232 & 245 & 251 & 278 & 296 \\
\hline & LR & 257 & 272 & 281 & 285 & 306 & 310 \\
\hline & NB & 150 & 132 & 122 & 149 & 156 & 159 \\
\hline \multirow{2}{*}{$\begin{array}{c}\text { Africa-Middle } \\
\text { East }\end{array}$} & LRC & & & & 240 & 444 & 450 \\
\hline & LRH & 377 & 371 & 376 & 369 & 375 & 363 \\
\hline
\end{tabular}




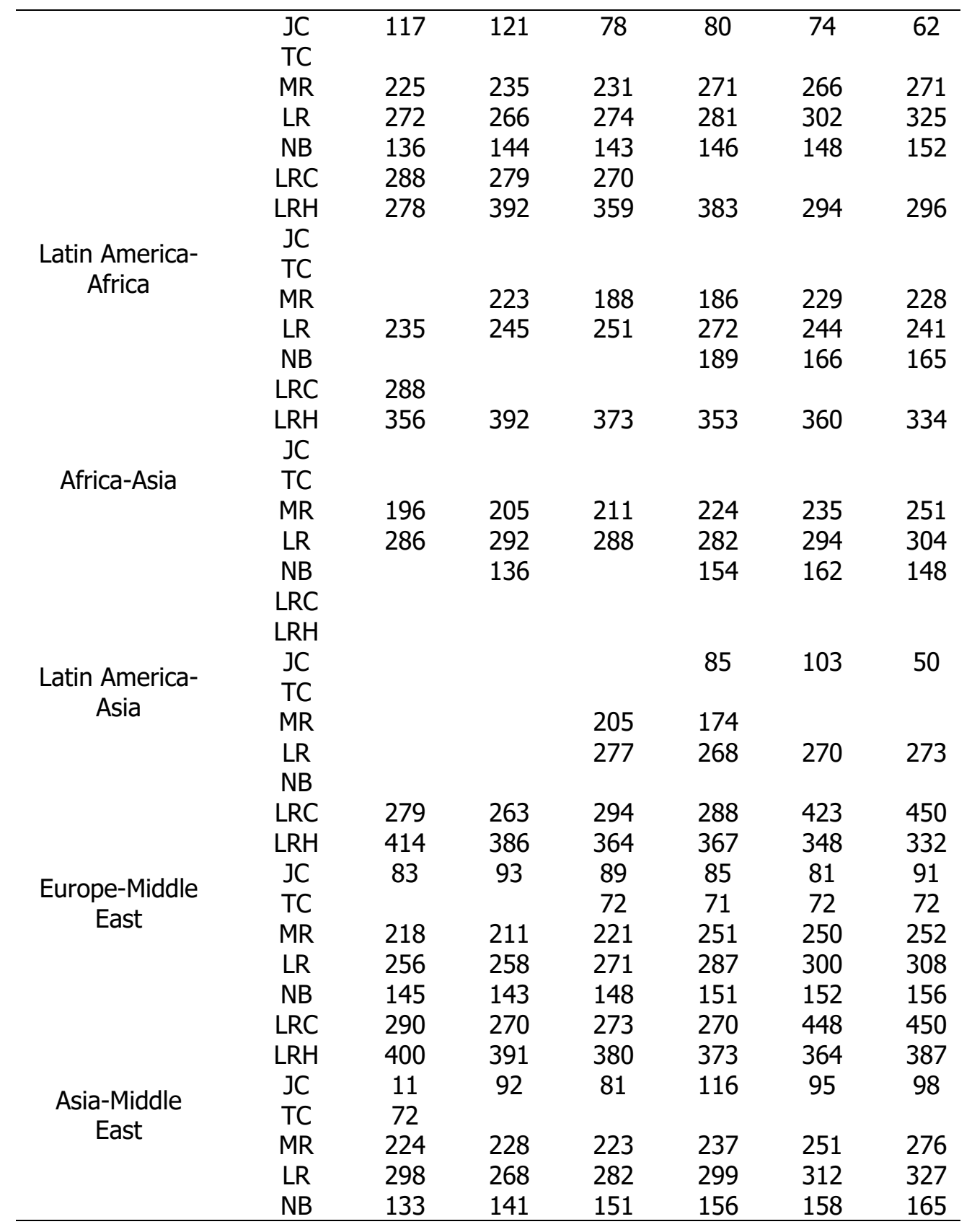


Appendix 12: Historical Development of Aircraft Seat Capacities for LCC IntraRegional Flights

\begin{tabular}{|c|c|c|c|c|c|c|c|}
\hline $\begin{array}{l}\text { Route } \\
\text { Group }\end{array}$ & $A / C$ & 2000 & 2004 & 2008 & 2012 & 2014 & 2016 \\
\hline \multirow{6}{*}{$\begin{array}{l}\text { Intra North } \\
\text { America }\end{array}$} & LRC & & & & & & \\
\hline & $\mathrm{LRH}$ & 480 & & & & & \\
\hline & $\mathrm{JC}$ & 120 & 61 & 86 & 97 & 103 & 103 \\
\hline & $\mathrm{TC}$ & & & & & & \\
\hline & MR & 192 & 217 & 224 & 221 & 222 & 225 \\
\hline & LR & & & & & & \\
\hline \multirow{9}{*}{ Intra Europe } & NB & 132 & 136 & 135 & 138 & 145 & 151 \\
\hline & LRC & 290 & & & & & \\
\hline & LRH & & & & & & \\
\hline & $\mathrm{JC}$ & 98 & 90 & 71 & 88 & 90 & 89 \\
\hline & $\mathrm{TC}$ & & 72 & 66 & 71 & 69 & 68 \\
\hline & MR & 190 & 241 & 250 & 222 & 251 & 262 \\
\hline & LR & 295 & 267 & & & 359 & 270 \\
\hline & NB & 146 & 157 & 167 & 174 & 176 & 178 \\
\hline & LRC & & & & & & \\
\hline \multirow{6}{*}{$\begin{array}{l}\text { Intra Middle } \\
\text { East }\end{array}$} & LRH & & & & 420 & 400 & \\
\hline & $\mathrm{JC}$ & & & & 98 & & \\
\hline & $\mathrm{TC}$ & & & & & & \\
\hline & MR & & & & 210 & 315 & 346 \\
\hline & LR & & & & & & \\
\hline & NB & & 150 & 150 & 173 & 166 & 167 \\
\hline \multirow{7}{*}{ Intra Africa } & LRC & & & & & & \\
\hline & LRH & & & & & & \\
\hline & $\mathrm{JC}$ & & 81 & 118 & 50 & 73 & 56 \\
\hline & $\mathrm{TC}$ & & & & & & \\
\hline & MR & 214 & 242 & 259 & 214 & 261 & 259 \\
\hline & LR & & & & & & \\
\hline & NB & 150 & 156 & 166 & 169 & 177 & 176 \\
\hline \multirow{7}{*}{$\begin{array}{l}\text { Intra Latin } \\
\text { America }\end{array}$} & LRC & & & & & & \\
\hline & LRH & & & & & & \\
\hline & $\mathrm{JC}$ & & & 66 & 105 & 105 & 106 \\
\hline & $\mathrm{TC}$ & & & & 72 & 68 & 70 \\
\hline & MR & 267 & 232 & 225 & 214 & 259 & 263 \\
\hline & LR & 332 & 267 & & & 272 & 267 \\
\hline & NB & 114 & 136 & 145 & 157 & 164 & 165 \\
\hline \multirow{7}{*}{ Intra Asia } & LRC & & & & & & \\
\hline & LRH & & 436 & & 420 & & 420 \\
\hline & $\mathrm{JC}$ & & 115 & 125 & & & 97 \\
\hline & $\mathrm{TC}$ & & & 66 & 66 & 72 & 72 \\
\hline & MR & 268 & 221 & 243 & 305 & 330 & 352 \\
\hline & LR & & 267 & 307 & 278 & 275 & 402 \\
\hline & NB & 151 & 149 & 164 & 172 & 180 & 181 \\
\hline
\end{tabular}


Appendix 13: Historical Development of Aircraft Seat Capacities for LCC InterRegional Flights

\begin{tabular}{|c|c|c|c|c|c|c|c|}
\hline Route Group & A/C & 2000 & 2004 & 2008 & 2012 & 2014 & 2016 \\
\hline \multirow{7}{*}{$\begin{array}{l}\text { North America- } \\
\text { Europe }\end{array}$} & LRC & & & & & & \\
\hline & LRH & 480 & 392 & 379 & 338 & 332 & 332 \\
\hline & $\mathrm{JC}$ & & & & & & \\
\hline & TC & & & & & & \\
\hline & MR & 269 & 264 & 251 & 220 & 256 & 273 \\
\hline & LR & & & 313 & 304 & 314 & 323 \\
\hline & NB & & & & & 136 & 170 \\
\hline \multirow{7}{*}{ Europe-Asia } & LRC & & & & & & \\
\hline & LRH & & & 371 & 338 & & \\
\hline & $\mathrm{JC}$ & & & & & & \\
\hline & TC & & & & & & \\
\hline & MR & 269 & 243 & 266 & 253 & 236 & 255 \\
\hline & LR & & 267 & & 285 & 257 & 320 \\
\hline & NB & & & 121 & 180 & 185 & 184 \\
\hline \multirow{7}{*}{$\begin{array}{l}\text { Asia-North } \\
\text { America }\end{array}$} & LRC & & & & & & \\
\hline & LRH & & & 359 & & & \\
\hline & $\mathrm{JC}$ & & & & & & \\
\hline & TC & & & & & & \\
\hline & MR & & & & & & \\
\hline & LR & & & & & & 390 \\
\hline & NB & & & & & & \\
\hline \multirow{7}{*}{$\begin{array}{l}\text { North America- } \\
\text { Latin America }\end{array}$} & LRC & & & & & & \\
\hline & LRH & 480 & & & & & \\
\hline & JC & & & 95 & 100 & 100 & 100 \\
\hline & TC & & & & & & \\
\hline & MR & 222 & 226 & 200 & 210 & & 220 \\
\hline & LR & & & & & 272 & 267 \\
\hline & NB & 112 & 139 & 148 & 151 & 156 & 161 \\
\hline \multirow{7}{*}{$\begin{array}{l}\text { North America- } \\
\text { Middle East }\end{array}$} & LRC & & & & & & \\
\hline & LRH & 480 & & & & & \\
\hline & JC & & & & & & \\
\hline & $\mathrm{TC}$ & & & & & & \\
\hline & MR & & & & & & \\
\hline & LR & & & & & & \\
\hline & NB & & & & & & \\
\hline \multirow{7}{*}{$\begin{array}{l}\text { North America- } \\
\text { Africa }\end{array}$} & LRC & & & & & & \\
\hline & LRH & & & & & & \\
\hline & $\mathrm{JC}$ & & & & & & \\
\hline & $\mathrm{TC}$ & & & & & & \\
\hline & MR & & & & & & \\
\hline & LR & & & & & & \\
\hline & NB & & & & & & \\
\hline \multirow{7}{*}{ Europe- Africa } & LRC & & & & & & \\
\hline & LRH & & & & & 420 & \\
\hline & $\mathrm{JC}$ & & & 91 & 100 & 112 & \\
\hline & $\mathrm{TC}$ & & & & & & \\
\hline & MR & 215 & 243 & 262 & 234 & 262 & 263 \\
\hline & LR & 311 & 267 & & & 358 & 287 \\
\hline & NB & 151 & 181 & 172 & 176 & 180 & 181 \\
\hline \multirow{7}{*}{$\begin{array}{l}\text { Latin America- } \\
\text { Europe }\end{array}$} & LRC & & & & & & \\
\hline & LRH & & & & & & \\
\hline & $\mathrm{JC}$ & & & & & & \\
\hline & $\mathrm{TC}$ & & & & & & \\
\hline & MR & 257 & 248 & 258 & 214 & 260 & 261 \\
\hline & LR & 325 & 267 & & & & 275 \\
\hline & NB & & & & & & \\
\hline Africa-Middle & LRC & & & & & & \\
\hline East & LRH & & & & & & \\
\hline
\end{tabular}




\begin{tabular}{|c|c|c|c|c|c|c|c|}
\hline & $\mathrm{JC}$ & & & & 98 & & \\
\hline & TC & & & & & & \\
\hline & MR & & & 265 & 210 & 321 & 310 \\
\hline & LR & & & & & & \\
\hline & NB & & 150 & 155 & 163 & 164 & 165 \\
\hline & LRC & & & & & & \\
\hline & LRH & & & & & & \\
\hline Latin America- & $\mathrm{JC}$ & & & & & & \\
\hline frica & TC & & & & & & \\
\hline & MR & & & & & & \\
\hline & LR & & & & & & \\
\hline & NB & & & & 150 & & \\
\hline & LRC & & & & & & \\
\hline & LRH & & & & & & \\
\hline & $\mathrm{JC}$ & & & & & & \\
\hline Africa-Asia & TC & & & & & & \\
\hline & MR & & & & & & 377 \\
\hline & LR & & & & & & \\
\hline & NB & & & & & 176 & 122 \\
\hline & LRC & & & & & & \\
\hline & LRH & & & & & & \\
\hline Latin America- & $\mathrm{JC}$ & & & & & & \\
\hline Asja & TC & & & & & & \\
\hline & MR & & & & & & \\
\hline & LR & & & & & & \\
\hline & NB & & & & & 180 & \\
\hline & LRC & & & & & & \\
\hline & LRH & 480 & & & & & \\
\hline Europe-Middle & JC & & & 90 & 98 & 111 & \\
\hline East & TC & & & & & & \\
\hline & MR & 216 & 234 & 266 & 215 & 309 & 267 \\
\hline & $\begin{array}{l}\text { LR } \\
\text { NB }\end{array}$ & & & 163 & 177 & 176 & $\begin{array}{l}350 \\
177\end{array}$ \\
\hline & LRC & & & & & & \\
\hline & LRH & & & & 420 & 397 & 420 \\
\hline & JC & & & & 98 & & \\
\hline East & $\mathrm{TC}$ & & & & & & \\
\hline & MR & 217 & 233 & 267 & 323 & 392 & 387 \\
\hline & $\begin{array}{l}\text { LR } \\
\text { NB }\end{array}$ & & 150 & 172 & 173 & 175 & 180 \\
\hline
\end{tabular}




\section{Appendix 14: Maximum Possible Seat Capacity per Aircraft Type}

\begin{tabular}{|c|c|c|c|}
\hline $\begin{array}{l}\text { Aircraft } \\
\text { Cluster }\end{array}$ & $\begin{array}{l}\text { SPECIFICACFT } \\
\text { (OAG) }\end{array}$ & $\begin{array}{l}\text { SPECIFICACFTNAME } \\
\text { (OAG) }\end{array}$ & $\begin{array}{c}\text { Maximum Possible Seats } \\
\text { per Aircraft }\end{array}$ \\
\hline LRC & M11 & $\begin{array}{c}\text { Boeing (Douglas) MD-11 } \\
\text { Passenger }\end{array}$ & 410 \\
\hline LRC & $74 M$ & $\begin{array}{c}\text { Boeing } 747 \text { (Mixed } \\
\text { Configuration) }\end{array}$ & 264 \\
\hline LRC & 74E & $\begin{array}{l}\text { Boeing 747-400 (Mixed } \\
\text { Configuration) }\end{array}$ & 264 \\
\hline LRH & 380 & Airbus $\mathrm{A} 380-800$ Passenger & 853 \\
\hline LRH & 747 & Boeing 747 (Passenger) & 624 \\
\hline LRH & 743 & $\begin{array}{c}\text { Boeing 747-300 /747-100 } \\
\text { /200 Sud (Pax) }\end{array}$ & 624 \\
\hline LRH & 744 & Boeing 747-400 (Passenger) & 624 \\
\hline LRH & 773 & Boeing 777-300 Passenger & 550 \\
\hline $\mathrm{JC}$ & 318 & Airbus A318 & 132 \\
\hline $\mathrm{JC}$ & AR1 & Avro RJ100 & 112 \\
\hline $\mathrm{JC}$ & AR8 & Avro RJ85 & 100 \\
\hline JC & $72 \mathrm{~F}$ & Boeing 727 (Freighter) & 0 \\
\hline $\mathrm{JC}$ & $73 \mathrm{~F}$ & Boeing 737 (Freighter) & 0 \\
\hline $\mathrm{JC}$ & 732 & Boeing 737-200 Passenger & 130 \\
\hline $\mathrm{JC}$ & 736 & Boeing 737-600 Passenger & 130 \\
\hline $\mathrm{JC}$ & CRJ & Canadair Regional Jet & 90 \\
\hline $\mathrm{JC}$ & CR2 & Canadair Regional Jet 200 & 50 \\
\hline $\mathrm{JC}$ & CR7 & Canadair Regional Jet 700 & 78 \\
\hline $\mathrm{JC}$ & CR9 & Canadair Regional Jet 900 & 90 \\
\hline $\mathrm{JC}$ & E70 & Embraer 170 & 78 \\
\hline JC & E75 & Embraer 175 & 88 \\
\hline $\mathrm{JC}$ & E90 & Embraer 190 & 114 \\
\hline $\mathrm{JC}$ & ERJ & Embraer RJ 135 /140 /145 & 50 \\
\hline $\mathrm{JC}$ & ER4 & Embraer RJ145 & 50 \\
\hline $\mathrm{JC}$ & 100 & Fokker 100 & 109 \\
\hline $\mathrm{JC}$ & TU3 & Tupolev TU134 & 76 \\
\hline $\mathrm{TC}$ & AT7 & ATR 72 & 70 \\
\hline MR & AB6 & Airbus A300-600 Passenger & 345 \\
\hline MR & 310 & Airbus A310 Passenger & 265 \\
\hline MR & 313 & Airbus A310-300 Passenger & 265 \\
\hline MR & 330 & Airbus $\mathrm{A} 330$ & 440 \\
\hline MR & 333 & Airbus A330-300 & 440 \\
\hline MR & 757 & Boeing 757 (Passenger) & 280 \\
\hline MR & $75 \mathrm{~W}$ & $\begin{array}{c}\text { Boeing 757-200 (winglets) } \\
\text { Passenger }\end{array}$ & 228 \\
\hline MR & 752 & Boeing 757-200 Passenger & 228 \\
\hline MR & 753 & Boeing 757-300 Passenger & 280 \\
\hline MR & 767 & Boeing 767 Passenger & 350 \\
\hline MR & 762 & Boeing 767-200 Passenger & 255 \\
\hline MR & 763 & Boeing 767-300 Passenger & 350 \\
\hline MR & T20 & Tupolev TU-204 /tu-214 & 210 \\
\hline LR & 332 & Airbus A330-200 & 380 \\
\hline LR & 340 & Airbus A340 & 440 \\
\hline LR & 342 & Airbus A340-200 & 300 \\
\hline LR & 343 & Airbus A340-300 & 440 \\
\hline LR & 345 & Airbus $A 340-500$ & 375 \\
\hline LR & 346 & Airbus A340-600 & 475 \\
\hline LR & 764 & Boeing 767-400 Passenger & 375 \\
\hline LR & 777 & Boeing 777 Passenger & 451 \\
\hline
\end{tabular}




\begin{tabular}{cccc}
\hline LR & 772 & Boeing 777-200 Passenger \\
LR & $77 L$ & Boeing 777-200LR & 440 \\
LR & $77 W$ & $\begin{array}{c}\text { Boeing 777-300ER } \\
\text { Passenger }\end{array}$ & 375 \\
LR & IL9 & Ilyushin II-96 Passenger & 451 \\
NB & $32 S$ & Airbus A318/ 319/320 /321 & 300 \\
NB & 319 & Airbus A319 & 220 \\
NB & 320 & Airbus A320 & 156 \\
NB & 321 & Airbus A321 & 180 \\
NB & M80 & Boeing (Douglas) MD-80 & 220 \\
NB & M81 & Boeing (Douglas) MD-81 & 172 \\
NB & M82 & Boeing (Douglas) MD-82 & 172 \\
NB & M83 & Boeing (Douglas) MD-83 & 172 \\
NB & M88 & Boeing (Douglas) MD-88 & 172 \\
NB & M90 & Boeing (Douglas) MD-90 & 172 \\
NB & 717 & Boeing 717-200 & 172 \\
NB & 737 & Boeing 737 Passenger & 117 \\
NB & 733 & Boeing 737-300 Passenger & 189 \\
NB & 734 & Boeing 737-400 Passenger & 149 \\
NB & 735 & Boeing 737-500 Passenger & 168 \\
NB & $73 W$ & Boeing 737-700 (winglets) & 132 \\
NB & $73 G$ & Passenger & 149 \\
NB & $73 H$ & Boeing 737-700 Passenger & 149 \\
NB & 738 & Boeing 737-800 (winglets) & 189 \\
NB & 739 & Boeing 737-900 Passenger & 189 \\
NB & D9S & McD-Douglas DC9 30 /40 & 189 \\
NB & TU5 & /50 & 139 \\
\hline & & Tupolev TU154 & 180 \\
\hline
\end{tabular}

\section{REFERENCES}

- ACI. (2016). Airline strategies and business models. 2016 Airline Planning Workshop. Retrieved from http://aci-na.org/sites/default/files/03airline_strategies_and_bus_models.pdf

- Airbus. (2008). Global Investor Forum 2008. Retrieved from https://www.airbusgroup.com/.../gif2008_workshop_commercial_market_leahy.pdf

- Berster, P., Gelhausen, M. C., \& Wilken, D. (2015). Is increasing aircraft size common practice of airlines at congested airports? Journal of Air Transport Management, 46, 4048. https://doi.org/10.1016/j.jairtraman.2015.03.012

- Bieger, T., \& Wittmer, A. (2006). Air transport and tourism - Perspectives and challenges for destinations, airlines and governments. Journal of Air Transport. (12), 40-46.

- Boeing Commercial Airplanes. (2014). Boeing Current Market Outlook 2014-2033. Retrieved from http://www.boeing.com/assets/pdf/commercial/cmo/pdf/Boeing_Current_Market_Outloo k_2014.pdf

- Boeing Commercial Airplanes. (2015). Airline Strategies and Business Models. Retrieved from http://www.boeing.com/commercial/market/long-term-market/airline-strategiesand-business-models/

- Boeing Commercial Airplanes. (2017). Current Market Outlook: 2017-2036.

- British Airways. (2016). Boeing 767-300. Retrieved from https://www.britishairways.com/en-gb/information/about-ba/fleet-facts/boeing-767-300 
- CAPA. (2013). Premium air travel: structural demand slide provides revenue headwind, but who is most exposed? Retrieved from https://centreforaviation.com/insights/analysis/premium-air-travel-structural-demandslides-provides-revenue-headwind-but-who-is-most-exposed-111132

- Clark, P. (2007). Buying the big jets: Fleet planning for airlines (2nd ed.). Aldershot, Hampshire, England, Burlington, VT: Ashgate Pub.

- Clark, P. (2017). Buying the big jets: Fleet planning for airlines / Paul Clark (Third edition). London: Routledge.

- DLR. (2016). Low Cost Monitor 1/2016. Retrieved from http://www.dlr.de/dlr/Portaldata/1/Resources/documents/2016/Low_Cost_Monitor_I_20 16.pdf

- Doganis, R. (2002). Flying off course: The economics of international airlines (3rd ed.). London, New York: Routledge.

- Dron, A. (2015). Interiors: Airbus gains traction with Space-Flex concept. Retrieved from https://www.flightglobal.com/news/articles/interiors-airbus-gains-traction-with-spaceflex-concept-410192/

- DVB Aviation Research. (2015). An Overview of Commercial Aircraft 2015-2016. Retrieved from http://www.dvbbank.com/ /media/Files/D/Dvb-Bank-Corp/documents/dvbaviation-finance-commerical-aircraft-booklet-2015-2016.pdf

- Giarratani, F., Hewings, G.J.D., \& McCann, P. (2013). Handbook of Industry Studies and Economic Geography: Edward Elgar Publishing. Retrieved from https://books.google.de/books?id=Ty5jAgAAQBAJ

- Gillen, D., \& Gados, A. (2008). Airlines within airlines: Assessing the vulnerabilities of mixing business models. Research in Transportation Economics, 24(1), 25-35.

- Givoni, M., \& Rietveld, P. (2009). Airline's choice of aircraft size - Explanations and implications. Transportation Research Part a: Policy and Practice, 43(5), 500-510. https://doi.org/10.1016/j.tra.2009.01.001

- Givoni, M., \& Rietveld, P. (2010). The environmental implications of airlines' choice of aircraft size. Journal of Air Transport Management, 16(3), 159-167. https://doi.org/10.1016/j.jairtraman.2009.07.010

- Heinz, S., \& O'Connell, J. F. (2013). Air transport in Africa: toward sustainable business models for African airlines. Journal of Transport Geography, 31(31), 72-83.

- ICAO. (2013). Glossary. Retrieved from www.icao.int/dataplus_archive/Documents/GLOSSARY.docx

- ICAO. (2014). List of LCC based on ICAO definition. Retrieved from http://www.icao.int/sustainability/Documents/LCC-List.pdf

- ICAO. (2015). Continuing Traffic Growth and Record Airline Profits Highlight 2015. Air Transport Results. Retrieved from http://www.icao.int/Newsroom/NewsDoc2015/COM.72.15.EN.pdf

- ICAO. (2017). Traffic growth and airline profitability were highlights of air transport in 2016. Retrieved from http://www.icao.int/Newsroom/Pages/traffic-growth-and-airlineprofitability-were-highlights-of-air-transport-in-2016.aspx

- IPCC. (1999). Aviation and the global atmosphere: A special report of IPCC Working Groups I and III in collaboration with the Scientific Assessment Panel to the Montreal Protocol on Substances that Deplete the Ozone Layer. Cambridge: Cambridge University Press.

- Ishka. (2017). A review of start-up airlines in 2016. Retrieved from http://www.ishkaglobal.com/News/Article/5558/A-review-of-start-up-airlines-in-2016

- Klemm, M. (2015). Airline Business Model Clustering. Technische Universität München.

- Kownatzki, M. (2011). Factors Influencing Aircraft Seat Configuration, or "How Many Seats are Really in an A380". Retrieved from http://planestats.com/Files/20110404_Seat_Configuration_Drivers.pdf 
- Kremser, F., Guenzkofer, F., Sedlmeier, C., Sabbah, O., \& Bengler, K. (2012). Aircraft seating comfort: The influence of seat pitch on passengers' well-being. Work (Reading, Mass.), 41 Suppl 1, 4936-4942. https://doi.org/10.3233/WOR-2012-0789-4936

- Leigh Fisher. (2015). The Viability of Long-Haul Low-Cost Carrier Service. Retrieved from http://www.leighfisher.com/sites/default/files/free_files/focus_-_the_viability_of_longhaul_low-cost_carrier_service_-_may_2015_0.pdf

- Magill, D. (2004). Low Cost Carrier Market. Retrieved from http://web.mit.edu/airlines/conferences/DC-2004_documents/04-DC2004-Magill1.pdf

- Miyoshi, C., \& Mason, K. J. (2009). The carbon emissions of selected airlines and aircraft types in three geographic markets. Journal of Air Transport Management, 15(3), 138-147. https://doi.org/10.1016/j.jairtraman.2008.11.009

- Nita, M., \& Scholz, D. (2010). From Preliminary Aircraft Cabin Design to Cabin Optimization. In Deutscher Luft- und Raumfahrtkongress 2010.

- OAG. (2000). Official Airline Guide Schedules Data, 2000. Retrieved from Subscription Service

- OAG. (2004). Official Airline Guide Schedules Data, 2004. Retrieved from Subscription Service

- OAG. (2008). Official Airline Guide Schedules Data, 2008. Retrieved from Subscription Service

- OAG. (2012). Official Airline Guide Schedules Data, 2012. Retrieved from Subscription Service

- OAG. (2014). Official Airline Guide Schedules Data, 2014. Retrieved from Subscription Service

- OAG. (2016). Official Airline Guide Schedules Data, 2016. Retrieved from Subscription Service

- Pai, V. (2010). On the factors that affect airline flight frequency and aircraft size. Journal of Air Transport Management, 16(4), 169-177. https://doi.org/10.1016/j.jairtraman.2009.08.001

- Pitt, I. L., \& Norsworthy, J. R. (2013). Economics of the U.S. Commercial Airline Industry: Productivity, Technology and Deregulation: Springer Verlag.

- Rahner, M. (2017). "Smart Cabin Reconfiguration" is honored with a highly coveted award. Retrieved from https://www.recaro-as.com/en/press/press-releases/details/smart-cabinreconfiguration-is-honored-with-a-highly-covetedaward.html?file=files/3_RECARO_Aircraft_Seating/Presse/Pressemitteilungen/2017/1704 04_Smart-Cabin-Reconfiguration-ausgezeichnet/RECARO_PR_CCA_EN.pdf

- Randt, N. P. (2016). Aircraft Technology Assessment Using Fleet-Level Metrics (PhD Dissertation). Technische Universität München, Garching. Retrieved from http://mediatum.ub.tum.de/doc/1277838/document.pdf

- Randt, N. P., Jessberger, C., \& Ploetner, K. O. (2015). Estimating the Fuel Saving Potential of Commercial Aircraft in Future Fleet-Development Scenarios. In 15th AIAA Aviation Technology, Integration, and Operations Conference. https://doi.org/10.2514/6.20152435

- Raymer, D. P. (1992). Aircraft design: A conceptual approach / Daniel P. Raymer (2nd ed.). AIAA education series. Washington, D.C.: American Institute of Aeronautics and Astronautics.

- Saab Press Center. (2015). Saab Signs Contract With Airbus for A321 ACF Door Plug. Retrieved from https://saabgroup.com/globalassets/cision/documents/2015/20150901saab-signs-contract-with-airbus-for-a321-acf-door-plug-en-1-1047169.pdf

- Schmidt, M. (2018). Ground-Operational Assessment of Novel Aircraft Cabin Configurations (Dissertation). Technische Universität München, Munich.

- Stimac, I., Vince, D., \& Vidovic, A. (2012). Effect of economic crisis on the changes of lowcost carriers business models. Retrieved from https://bib.irb.hr/datoteka/585730.Stimac_Vince_Vidovic.pdf

- Vidović, A., Štimac, I., \& Vince, D. (2013). DEVELOPMENT OF BUSINESS MODELS OF LOWCOST AIRLINES. International Journal for Traffic and Transport Engineering, 3 (1), 6981. https://doi.org/10.7708/ijtte.2013.3(1).07 